Supporting Information for

\title{
Molecular Cu(I)-Cu(II) Photosensitizer-Catalyst Photoelectrode for Water Oxidation
}

\author{
Zujhar Singh, P. Rafael Donnarumma, and Marek B. Majewski* \\ Department of Chemistry and Biochemistry and Centre for NanoScience Research Concordia \\ University, 7141 Sherbrooke Street West, Montreal, Quebec, Canada, H4B 1R6 \\ E-mail: marek.majewski@concordia.ca
}

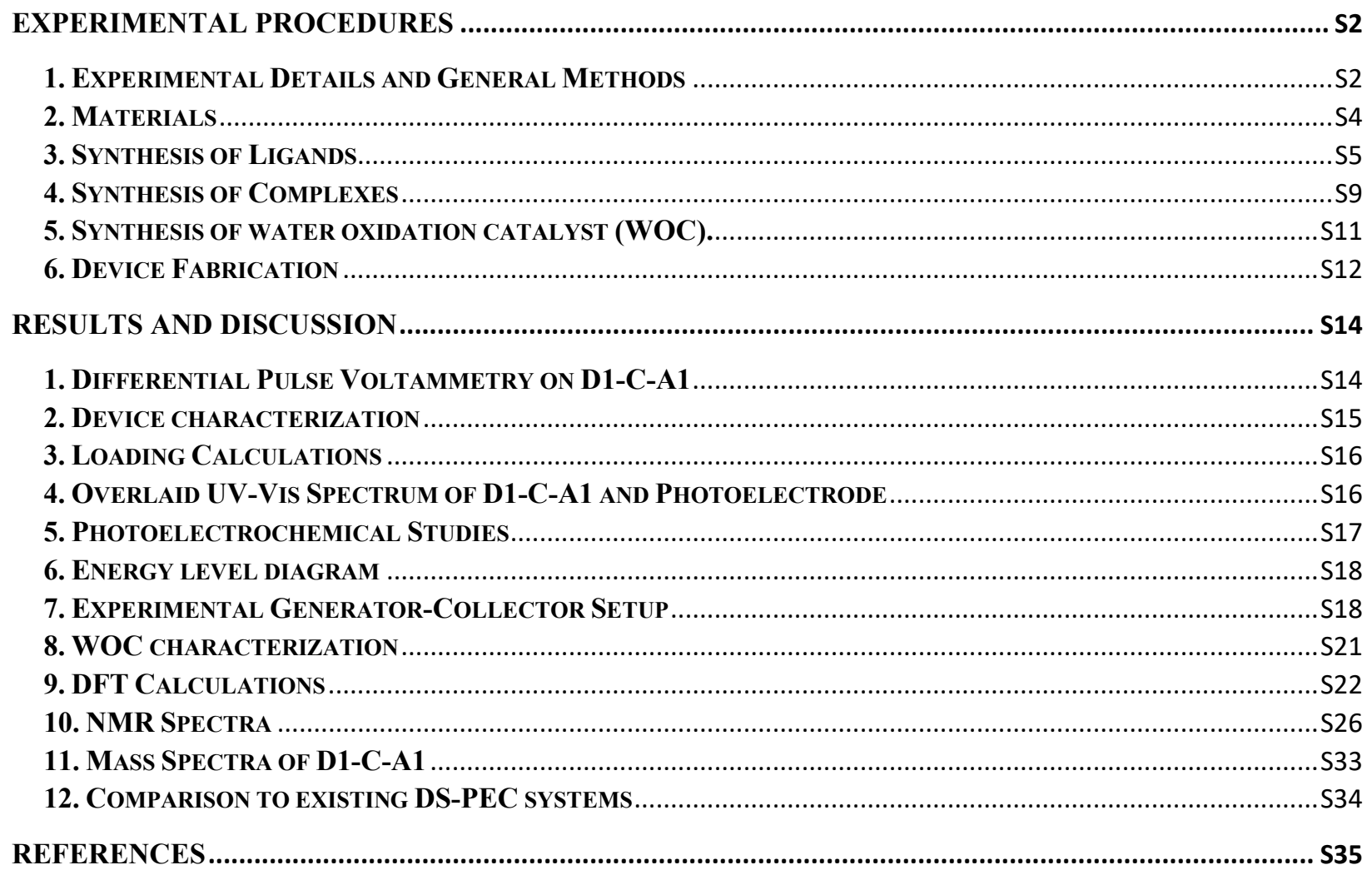




\section{Experimental Procedures}

\section{Experimental Details and General Methods}

All moisture sensitive reactions were carried out using standard Schlenk line techniques under an inert atmosphere of nitrogen. The ligands and complexes were prepared using modifications of previously reported methods. ${ }^{1,2}$ Purification was performed using conventional column chromatography on silica. ${ }^{1} \mathrm{H}$ NMR and ${ }^{13} \mathrm{C}$ NMR were recorded on a $300 \mathrm{MHz}$ Bruker and a 500 $\mathrm{MHz}$ Varian spectrometer respectively and the chemical shifts were referenced to the residual solvent peaks. High resolution electrospray mass spectrometry (HR-ESI-MS) was performed using a Waters Model QTOF Ultima instrument. UV-Vis spectra were collected in $\mathrm{CH}_{2} \mathrm{Cl}_{2}$ using quartz cuvettes with a $1 \mathrm{~cm}$ pathlength using a dual beam Varian Cary 100 Bio UV-vis spectrophotometer with a wavelength changeover at $350 \mathrm{~nm}$ and scan rate of $10 \mathrm{~nm} \mathrm{~s}^{-1}$. Diffuse reflectance UV-Vis studies were carried out using a Cary 6000 Series UV-Vis-NIR spectrophotometer (Agilent Technologies) coupled with an integrating sphere. A $5.0 \mathrm{~nm}$ bandwidth with a wavelength changeover at $350 \mathrm{~nm}$ and a scan speed of $10 \mathrm{~nm} \mathrm{~s}^{-1}$ with a resolution of $1 \mathrm{~nm}$ were used for analysis.

Electrochemical measurements on the molecular species were performed using a WaveDriver 20 Integrated Bipotentiostat/Galvanostat workstation (Pine Research Instrumentation, Inc.) in a conventional three electrode cell using a Pt button $(2 \mathrm{~mm})$ as the working electrode, Pt wire as the counter electrode and Ag wire as the pseudoreference electrode. Copper complexes $(1 \mathrm{mM})$ and tetrabutylammonium hexafluorophosphate as electrolyte were dissolved in degassed $\mathrm{CH}_{2} \mathrm{Cl}_{2}$, and cyclic voltammetry measurements were taken under an argon atmosphere at scan rate of $100 \mathrm{mV} / \mathrm{s}$. Photoelectrochemical experiments were conducted using the same instrument in a three electrode cell configuration with ZnO NWs $\mid \mathbf{A 1 - C - D 1}$ or ZnO NWs $\mid$ A1-C as the working electrode with no 
applied bias, $\mathrm{Ag} / \mathrm{AgCl}$ as the pseudoreference electrode and $\mathrm{Pt}$ wire as the counter electrode. The working electrode was illuminated with white light (a four Cree XP-G3 warm white LED array). ${ }^{3}$ Oxygen was detected using the collector-generator dual electrode method as reported previously. Oxygen was generated at the ZnO NWs|A1-C-D1 films with and without catalyst. The cell was sparged with argon and the reference electrode and dual working electrodes were separated from counter electrode in an $\mathrm{H}$-cell by a glass frit. Enough bias $(-0.40 \mathrm{~V}$ vs. $\mathrm{Ag} / \mathrm{AgCl})$ was applied on the unfunctionalized FTO collector electrode to reduce oxygen generated at the generator electrode. The dual electrode was illuminated from the side on which ZnO NWs|A1-C-D1 is facing using white light (a four LED array, Cree XM-L2 warm white LEDs). Faradaic efficiencies for oxygen generation ( $\eta_{2}$ ) were calculated using chronocolumbic methods according to equation S1, where $\mathrm{Q}_{\mathrm{col}}$ and $\mathrm{Q}_{\mathrm{gen}}$ are the total charge passed at the collector and generator electrode and $\eta_{\text {coleff }}$ is the collection efficiency of the cell $(70 \%) .{ }^{3}$ The current trace at the collector electrode was integrated to get the total charge passed with respect to time and $\mathrm{Q}_{\mathrm{col}}$ is the difference of the charge at beginning of the light illumination vs charge $10 \mathrm{~s}$ before the end of illumination. Qgen is also calculated in the same fashion.

$$
\boldsymbol{\eta}_{o_{2}}=\left(\boldsymbol{Q}_{\text {col }} / \boldsymbol{Q}_{\text {gen }}\right)\left(1 /\left(\boldsymbol{\eta}_{\text {colleff }}\right) \quad\right. \text { Eqn. S1 }
$$

A FEI Quanta 3D FEG scanning electron microscope dual beam instrument working at $5 \mathrm{kV}$ was used to study morphology of the ZnO NWs. The films were sputter-coated with Pt before all measurements. Powder X-ray diffraction (PXRD) measurements were obtained on a 2nd Gen D2 Phaser X-ray diffractometer with monochromatized $\mathrm{Cu} \mathrm{K \alpha}$ radiation with a nickel filter (Bruker AXS). The voltage was $30 \mathrm{kV}$ and $10 \mathrm{~mA}$ with a PSD fast scan. Increments of 0.05 degrees and 1 
s per step with a PSD opening of 4.7970 degrees. The photoelectrode thickness was analyzed using a Dektak XT contact profilometer with a stylus force of $10 \mathrm{mg}$. Diffuse reflectance infrared spectra were recorded using a Thermo Scientific Nicolet 6700 FT-IR equipped with a MCT detector with resolution of 1 .

\section{Materials}

All chemicals were used as received. Activated 10\% palladium on carbon, 2,9-dimethyl-1,10phenanthroline (dmp), 4-(9H-carbazol-9-yl)-benzaldehyde, tetrakis(acetonitrile) copper(I) tetrafluoroborate, hexamethylene tetramine (HMTA), fluorine doped tin oxide (10 $\Omega$ ) on glass substrates, and zinc nitrate hexahydrate were purchased from Sigma-Aldrich. Hydrazine monohydrate, 4-bromonaphthalene-1,8-dicarboxyanhydride, (3-aminopropyl)triethoxysilane and ammonium acetate were purchased from TCI. Glacial acetic acid, nitric acid, and sulphuric acid were purchased from Fisher Scientific. 


\section{Synthesis of Ligands}

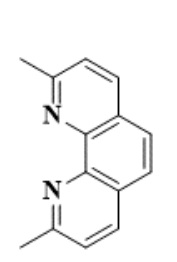

1

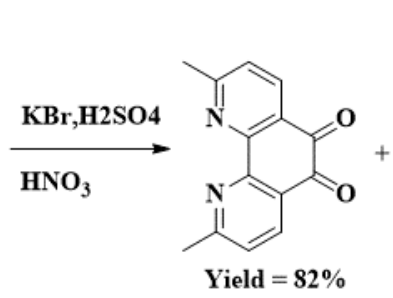

2

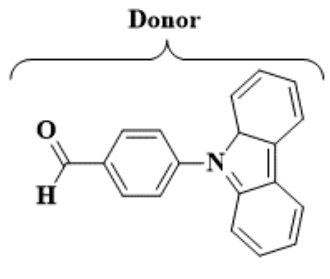

3

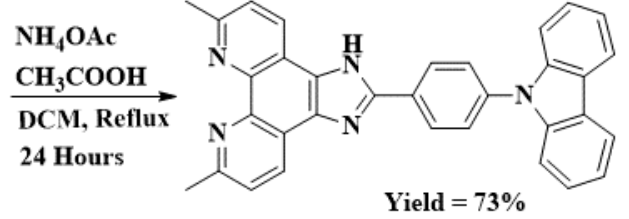

D1

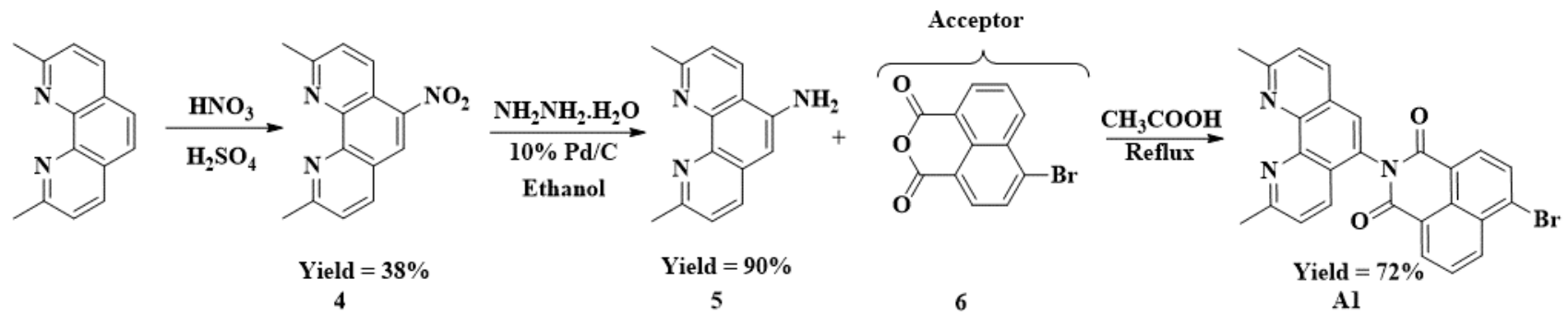

Scheme S1. General scheme for the synthesis of ligands A1 and D1

The synthesis of D1 follows oxidation of 2,9-dimethyl-1,10-phenanthroline (1) to 2,9-dimethyl1,10-phenanthroline-5,6-dione (2) which was then further coupled to a carbazole-substituted benzaldehyde (3) to yield D1 in 73\% yield. Synthesis of A1 was carried out in three steps starting with nitration of 1 using $\mathrm{HNO}_{3} / \mathrm{H}_{2} \mathrm{SO}_{4}$ to yield 5-nitro-2,9-dimethyl-1,10-phenanthroline (4) in $38 \%$ yield. In the second step, 2,9-dimethyl-1,10-phenanthroline-5,6-dione (2) was reduced over $10 \% \mathrm{Pd} / \mathrm{C}$ using hydrazine to produce 5-amino-2,9-dimethyl-1,10-phenanthroline (5) in near quantitative yield. The last step involved coupling of 5 with 4-bromo-1,8-naphthalic anhydride (6) in glacial acetic acid to give acceptor ligand $\mathbf{A 1}$ as a yellow solid in $72 \%$ yield. The identities of A1 and D1 were confirmed using ${ }^{1} \mathrm{H}$ NMR, ${ }^{13} \mathrm{C}$ NMR, HR-ESI mass spectrometry, and UV-Vis spectroscopic techniques. 
2,9-dimethyl-1,10-phenanthroline-5,6-dione (2). A round bottom flask was charged with 2,9-dimethyl1,10-phenanthroline 1 (1.00 g, $4.80 \mathrm{mmol})$ and $16 \mathrm{~mL}$ of $98 \% \mathrm{w} / \mathrm{w}$ sulfuric acid. The solution was cooled to $0{ }^{\circ} \mathrm{C}$ and potassium bromide $(5.60 \mathrm{~g}, 24.0 \mathrm{mmol})$ was added to the mixture. Nitric acid (7 $\mathrm{mL}$ ) was added slowly after stirring the solution for 15 minutes. The reaction mixture was heated to 80 ${ }^{\circ} \mathrm{C}$ for 3 hours, cooled to room temperature and transferred to a $500 \mathrm{~mL}$ beaker. To the solution was slowly added a saturated solution of $\mathrm{NaHCO}_{3}$ until gas evolution was no longer observed. The aqueous layer was extracted with $\mathrm{CH}_{2} \mathrm{Cl}_{2}(3 \times)$, dried over $\mathrm{Na}_{2} \mathrm{SO}_{4}$, filtered and the solvent was removed to yield a brown colored solid which was subsequently purified using column chromatography $(0.1 \% \mathrm{MeOH}$ in $\left.\mathrm{CH}_{2} \mathrm{Cl}_{2}\right)$. This solid was washed with hexane resulting in a light brown flaky solid of $2(0.70 \mathrm{~g}, 2.92$ mmol) in $61 \%$ yield.

${ }^{1} \mathrm{H}$ NMR $\left(500 \mathrm{MHz}, \mathrm{CDCl}_{3}\right) \delta 8.40(\mathrm{~d}, J=8.0 \mathrm{~Hz}, 2 \mathrm{H}), 7.44(\mathrm{~d}, J=8.0 \mathrm{~Hz}, 2 \mathrm{H}), 2.87(\mathrm{~s}, 6 \mathrm{H})$. HR-MS (ESI+): Calcd for $\mathrm{C}_{14} \mathrm{H}_{11} \mathrm{~N}_{2} \mathrm{O}_{2}\left([\mathrm{M}+\mathrm{H}]^{+}\right): m / z$ 239.082. Found: $m / z 239.079$

2-(4-(8a,9a-dihydro-9H-carbazol-9-yl)-phenyl)-6,9-dimethyl-1H-imidazo[4,5-f] [1,10]phenanthroline (D1). 4-(9H-carbazol-9-yl)-benzaldehyde (3) $(250 \mathrm{mg}, 0.91 \mathrm{mmol}), 2$ (200 mg, $0.84 \mathrm{mmol})$ and ammonium acetate $(1.42 \mathrm{~g}, 18.5 \mathrm{mmol})$ were all added to a two neck round bottom flask containing 50 $\mathrm{mL}$ of $\mathrm{CH}_{2} \mathrm{Cl}_{2}$ under $\mathrm{N}_{2}$. Glacial acetic acid $(1 \mathrm{~mL})$ was added, and the resulting solution was stirred at room temperature for 24 hours. After this reaction period, water $(100 \mathrm{~mL})$ was added and the aqueous layer was extracted with $\mathrm{CH}_{2} \mathrm{Cl}_{2}(3 \times)$. This $\mathrm{CH}_{2} \mathrm{Cl}_{2}$ was washed three times with $\mathrm{NaHCO}_{3}$ solution, dried over $\mathrm{Na}_{2} \mathrm{SO}_{4}$ and solvent was removed via rotary evaporation to yield $\mathbf{D 1}(310 \mathrm{mg}, 0.63 \mathrm{mmol})$ in $75 \%$ yield. 
${ }^{1} \mathrm{H}$ NMR (500 MHz, DMSO-d6) $\delta 13.78(\mathrm{~s}, 1 \mathrm{H}), 8.81(\mathrm{~d}, 2 \mathrm{H}), 8.55(\mathrm{~d}, J=8.3 \mathrm{~Hz}, 2 \mathrm{H}), 8.28(\mathrm{~d}, J$ $=7.8 \mathrm{~Hz}, 2 \mathrm{H}), 7.90(\mathrm{~d}, J=8.3 \mathrm{~Hz}, 2 \mathrm{H}), 7.70(\mathrm{~m}, 2 \mathrm{H}), 7.54(\mathrm{~d}, J=8.1 \mathrm{~Hz}, 2 \mathrm{H}), 7.49(\mathrm{t}, J=7.4 \mathrm{~Hz}$, $2 \mathrm{H}), 7.33(\mathrm{t}, J=7.3 \mathrm{~Hz}, 2 \mathrm{H}), 2.88-2.74(\mathrm{~s}, 6 \mathrm{H})$.

${ }^{13}$ C NMR (500 MHz, DMSO-d6) 156.48, 143.36, 140.35, 138.19, 130.40, 128.23, 127.48, 126.98, $126.84,123.75,123.40,121.06,120.78,110.29,25.85$.

HR-MS (ESI+): Calcd for $\mathrm{C}_{33} \mathrm{H}_{24} \mathrm{~N}_{5}\left([\mathrm{M}+\mathrm{H}]^{+}\right): \mathrm{m} / z$ 490.203 Found: $\mathrm{m} / z=490.160$

5-Nitro-2,9-dimethyl-1,10-phenanthroline (4). 2,9-dimethyl-1,10-phenanthroline 1 (500 mg, 2.40 mmol) was dissolved in $10 \mathrm{~mL}$ of concentrated sulfuric acid and heated to $115{ }^{\circ} \mathrm{C}$. Nitric acid $(5$ $\mathrm{mL}$ ) was added to the mixture and the resulting solution was heated at $115^{\circ} \mathrm{C}$ for 3 hours. Then, the hot solution was poured onto $100 \mathrm{~g}$ of ice and a concentrated (ca.5 N) solution of $\mathrm{NaOH}$ was added until a visible color change from yellow to green was observed $(\mathrm{pH}=8)$. Dilute nitric acid ( $1 \mathrm{~mL}$ in $20 \mathrm{~mL}$ of water) was added dropwise at last to precipitate 4 . The precipitates were filtered and dried at $110{ }^{\circ} \mathrm{C}$ in a vacuum oven to give 4 ( $180 \mathrm{mg}, 0.71 \mathrm{mmol}, 30 \%$ yield).

${ }^{1} \mathrm{H}$ NMR (500 MHz, CDCl $) \delta 8.93(\mathrm{~d}, J=8.7 \mathrm{~Hz}, 1 \mathrm{H}), 8.62(\mathrm{~s}, 1 \mathrm{H}), 8.28(\mathrm{~d}, J=8.2 \mathrm{~Hz}, 1 \mathrm{H}), 7.68$ (d, $J=8.7 \mathrm{~Hz}, 1 \mathrm{H}), 7.63(\mathrm{~d}, J=8.2 \mathrm{~Hz}, 1 \mathrm{H}), 3.01$ (s, 3H), 2.99 (s, 3H).

5-Amino-2,9-dimethyl-1,10-phenanthroline (5). To a suspension of $4(150 \mathrm{mg}, 0.59 \mathrm{mmol})$ in ethanol was added $10 \% \mathrm{w} / \mathrm{w} \mathrm{Pd} / \mathrm{C}(50 \mathrm{mg})$ under $\mathrm{N}_{2}$ atmosphere. The reaction mixture was kept under stirring and an excess of hydrazine monohydrate $(1.00 \mathrm{~mL}, 48.0 \mathrm{mmol})$ was added after $10 \mathrm{~min}$ over a period of 1 hour. The reaction mixture was held at reflux for 24 hours. The resulting black suspension was filtered on a Celite ${ }^{\circledR}$ pad. The solvent was removed via rotary evaporation and the resulting yellow solid was washed with water $(3 \times)$ and then re-dissolved in $\mathrm{CH}_{2} \mathrm{Cl}_{2}$. The resulting solution was dried 
over sodium sulfate and the solvent was removed to yield $\mathbf{5}$ as a yellow solid $(120 \mathrm{mg}, 0.53 \mathrm{mmol})$ in $90 \%$ yield.

${ }^{1} \mathrm{H}$ NMR $\left(500 \mathrm{MHz}, \mathrm{CDCl}_{3}\right) \delta 8.14(\mathrm{~d}, J=7.9 \mathrm{~Hz}, 1 \mathrm{H}), 7.85(\mathrm{~d}, J=8.1 \mathrm{~Hz}, 1 \mathrm{H}), 7.48(\mathrm{~d}, J=9.4$ Hz, 1H), 7.35 (d, J=15.6 Hz, 1H), $6.87(\mathrm{~s}, 1 \mathrm{H}), 4.13(\mathrm{~s}, 1 \mathrm{H}), 2.92(\mathrm{~s}, 3 \mathrm{H}), 2.86(\mathrm{~s}, 3 \mathrm{H})$.

HR-MS (ESI+): Calcd for $\mathrm{C}_{14} \mathrm{H}_{14} \mathrm{~N}_{3}\left([\mathrm{M}+\mathrm{H}]^{+}\right): m / z 224.118$ Found: $m / z=224.102$

6-bromo-2-(2,9-dimethyl-1,10-phenanthrolin-5-yl)-1H-benzo[de]isoquinoline-1,3(2H)-dione (A1). 4bromonaphthalene-1,8-dicarboxy-anhydride 6 (185 mg, $0.67 \mathrm{mmol})$ and 5 (150 $\mathrm{mg}, 0.67 \mathrm{mmol})$ were heated to reflux in glacial acetic acid $(15 \mathrm{~mL})$ for $24 \mathrm{~h}$. The solvent was removed using reduced pressure and resulting solid was washed with water and dried in a vacuum oven at $100{ }^{\circ} \mathrm{C}$ overnight. The crude black solid was purified using column chromatography on silica (1\% $\mathrm{MeOH}$ in $\mathrm{CH}_{2} \mathrm{Cl}_{2}$ ) to give $\mathbf{A 1}$ as a yellow solid in $59 \%$ yield.

${ }^{1} \mathrm{H}$ NMR $\left(500 \mathrm{MHz}, \mathrm{CDCl}_{3}\right) \delta 8.80-8.68(\mathrm{~m}, 2 \mathrm{H}), 8.50(\mathrm{~d}, J=7.8 \mathrm{~Hz}, 1 \mathrm{H}), 8.14(\mathrm{dd}, J=8.0,1.5$ $\mathrm{Hz}, 2 \mathrm{H}), 7.99-7.91(\mathrm{~m}, 1 \mathrm{H}), 7.88(\mathrm{~d}, J=4.8 \mathrm{~Hz}, 1 \mathrm{H}), 7.78(\mathrm{~s}, 1 \mathrm{H}), 7.54(\mathrm{~d}, J=8.2 \mathrm{~Hz}, 1 \mathrm{H}), 7.42$ (d, $J=8.5 \mathrm{~Hz}, 1 \mathrm{H}), 2.99(\mathrm{~s}, 3 \mathrm{H}), 2.94(\mathrm{~s}, 3 \mathrm{H})$.

${ }^{13} \mathrm{C}$ NMR (500 MHz, $\left.\mathrm{CDCl}_{3}\right)$ 163.81, 160.51, 159.87, 146.10, 145.54, 136.62, 134.14, 134.01, $132.85,131.96,131.42,131.29,131.01,130.83,129.61,129.49,128.37,126.28,126.03,123.97$, $123.92,123.85,122.93,122.02,26.06,25.86$.

HR-MS (ESI+): Calcd for $\mathrm{C}_{26} \mathrm{H}_{17} \mathrm{BrN}_{3} \mathrm{O}_{3}\left([\mathrm{M}+\mathrm{H}]^{+}\right): m / z$ 482.050 Found: $m / z=482.070$ 


\section{Synthesis of Complexes}
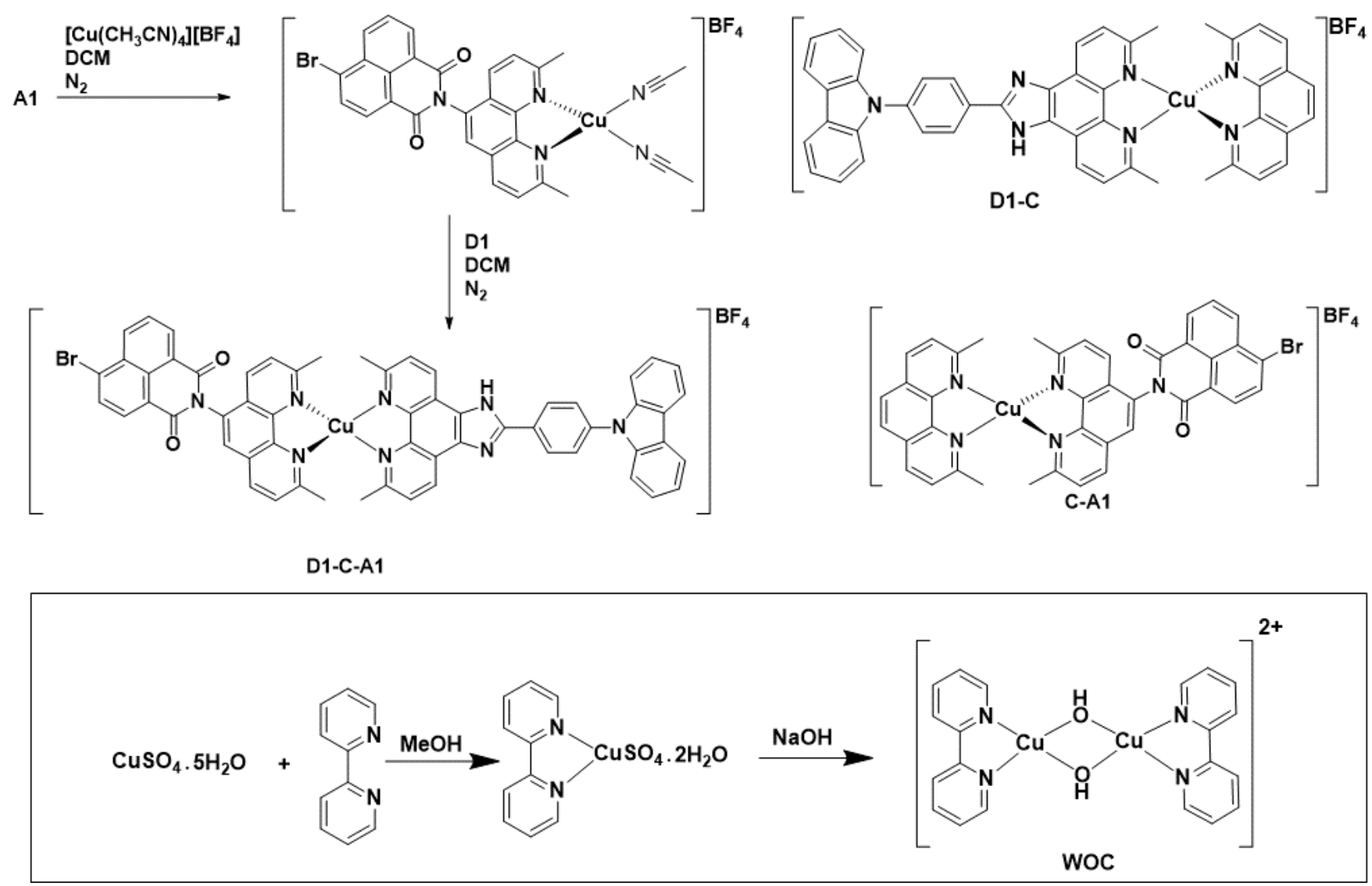

Scheme S2. Synthetic approach for synthesis of D1-C-A1, D1-C, C-A1 and WOC.

All the complexes were synthesized using the HETPhen approach reported in literature. ${ }^{4}$ In a representative procedure, tetrakis(acetonitrile) copper(I) tetrafluoroborate $(0.100 \mathrm{mmol})$ and one of the ligands $(0.100 \mathrm{mmol})$ were dissolved in degassed $\mathrm{CH}_{2} \mathrm{Cl}_{2}$ under $\mathrm{N}_{2}$. The yellow solution was stirred at room temperature for 20 minutes and then a solution of the second ligand $(0.100$ mmmol) dissolved in degassed $\mathrm{CH}_{2} \mathrm{Cl}_{2}$ under $\mathrm{N}_{2}$ was slowly added using a syringe. At this point, the reaction mixture turned red and was stirred for another 20 minutes at room temperature. Solvent was removed under reduced pressure to yield a dark red solid. This solid was then dissolved in a 
minimum amount of $\mathrm{CH}_{2} \mathrm{Cl}_{2}$ and reprecipitated by addition into diethyl ether. D1-C-A1 was further purified using column chromatography $\left(\mathrm{CH}_{2} \mathrm{Cl}_{2}\right)$.

$[C u(d m p)(D 1)] B F_{4},(D 1-C)$. The complex was isolated in $78 \%$ yield.

${ }^{1} \mathrm{H}$ NMR $\left(500 \mathrm{MHz}, \mathrm{CD}_{3} \mathrm{CN}\right) \delta 12.41(\mathrm{~s}, 1 \mathrm{H}), 8.59(\mathrm{~d}, J=8.1 \mathrm{~Hz}, 2 \mathrm{H}), 8.51(\mathrm{~d}, J=7.5 \mathrm{~Hz}, 2 \mathrm{H})$, $8.25(\mathrm{~d}, J=6.9 \mathrm{~Hz}, 2 \mathrm{H}), 8.10(\mathrm{~s}, 2 \mathrm{H}), 7.99(\mathrm{~s}, 2 \mathrm{H}), 7.92(\mathrm{~s}, 2 \mathrm{H}), 7.87-7.80(\mathrm{~m}, 2 \mathrm{H}), 7.60(\mathrm{~d}, J=$ $8.8 \mathrm{~Hz}, 2 \mathrm{H}), 7.55-7.46(\mathrm{t}, 2 \mathrm{H}), 7.41-7.30(\mathrm{~m}, 2 \mathrm{H}), 2.42(\mathrm{~s}, 6 \mathrm{H})$.

HR-MS (ESI+): Calcd for $\mathrm{C}_{47} \mathrm{H}_{35} \mathrm{CuN}_{7}\left(\left[\mathrm{M}-\mathrm{BF}_{4}\right]^{+}\right): m / z 760.22$ Found: $m / z=760.12$

$[C u(\boldsymbol{A 1})(\mathrm{dmp})] B F_{4},(\boldsymbol{C}-\boldsymbol{A 1})$. The complex was isolated in $83 \%$ yield.

${ }^{1} \mathrm{H}$ NMR (500 MHz, Acetone-d 6$) \delta 8.80$ (ddd, $\left.J=18.4,10.5,3.8 \mathrm{~Hz}, 5 \mathrm{H}\right), 8.55$ (dd, $J=7.6,4.2$ $\mathrm{Hz}, 1 \mathrm{H}), 8.45(\mathrm{~d}, J=7.7 \mathrm{~Hz}, 1 \mathrm{H}), 8.35(\mathrm{~d}, J=7.8 \mathrm{~Hz}, 1 \mathrm{H}), 8.25(\mathrm{~s}, 1 \mathrm{H}), 8.23(\mathrm{~s}, 2 \mathrm{H}), 8.15(\mathrm{t}, J=$ $7.8 \mathrm{~Hz}, 1 \mathrm{H}), 8.08(\mathrm{dd}, J=14.9,8.2 \mathrm{~Hz}, 1 \mathrm{H}), 8.01(\mathrm{~d}, J=8.3 \mathrm{~Hz}, 1 \mathrm{H}), 7.98(\mathrm{~d}, J=8.3 \mathrm{~Hz}, 2 \mathrm{H})$, $7.96-7.90(\mathrm{~m}, 1 \mathrm{H}) 2.60(\mathrm{~s}, 6 \mathrm{H}), 2.52(\mathrm{~s}, 6 \mathrm{H})$.

HR-MS (ESI+): Calcd for $\mathrm{C}_{40} \mathrm{H}_{28} \mathrm{BrCuN}_{5} \mathrm{O}_{2}\left(\left[\mathrm{M}-\mathrm{BF}_{4}\right]^{+}\right): m / z 752.07$ Found: $m / z=752.10$

$[C u(\boldsymbol{A 1})(\boldsymbol{D} 1)] B F_{4},(\boldsymbol{D} 1-\boldsymbol{C}-\boldsymbol{A} 1)$. Synthesis afforded D1-C-A1 in 70\% yield.

${ }^{1} \mathrm{H}$ NMR $\left(500 \mathrm{MHz}, \mathrm{DMSO}-\mathrm{d}_{3}\right) \delta 9.17(\mathrm{~d}, J=6.3 \mathrm{~Hz}, 2 \mathrm{H}), 8.87(\mathrm{~d}, J=8.5 \mathrm{~Hz}, 1 \mathrm{H}), 8.80(\mathrm{~d}, J=$ $8.2 \mathrm{~Hz}, 1 \mathrm{H}), 8.71(\mathrm{~d}, J=8.5 \mathrm{~Hz}, 1 \mathrm{H}), 8.68-8.62(\mathrm{~m}, 1 \mathrm{H}), 8.62(\mathrm{~d}, J=5.6 \mathrm{~Hz}, 2 \mathrm{H}), 8.42(\mathrm{~d}, J=$ $4.9 \mathrm{~Hz}, 1 \mathrm{H}), 8.34(\mathrm{~d}, J=7.6 \mathrm{~Hz}, 1 \mathrm{H}), 8.29(\mathrm{~d}, J=6.6 \mathrm{~Hz}, 2 \mathrm{H}), 8.15-8.09(\mathrm{~m}, 2 \mathrm{H}), 8.08-8.03$ $(\mathrm{m}, 2 \mathrm{H}), 7.97(\mathrm{~d}, J=5.9 \mathrm{~Hz}, 2 \mathrm{H}), 7.92(\mathrm{~d}, J=8.6 \mathrm{~Hz}, 1 \mathrm{H}), 7.56(\mathrm{~d}, J=7.4 \mathrm{~Hz}, 2 \mathrm{H}), 7.49(\mathrm{~m}, 2 \mathrm{H})$, $7.38-7.29(\mathrm{~m}, 2 \mathrm{H})$. 
${ }^{1} \mathrm{H}$ NMR (500 MHz, Acetone- $\left.\mathrm{d}_{6}\right) \delta 13.35(\mathrm{~s}, 1 \mathrm{H}), 8.86-8.74(\mathrm{~m}, 5 \mathrm{H}), 8.72(\mathrm{~s}, 2 \mathrm{H}), 8.55(\mathrm{dd}, J=$ 7.8, $3.5 \mathrm{~Hz}, 1 \mathrm{H}), 8.46(\mathrm{~s}, 1 \mathrm{H}), 8.35(\mathrm{dd}, J=7.8,2.4 \mathrm{~Hz}, 2 \mathrm{H}), 8.31-8.25(\mathrm{~m}, 1 \mathrm{H}), 8.19-8.11(\mathrm{~m}$, 1H), $8.09(\mathrm{dd}, J=8.1,5.1 \mathrm{~Hz}, 3 \mathrm{H}), 7.94(\mathrm{dd}, J=8.5,5.2 \mathrm{~Hz}, 3 \mathrm{H}), 7.59(\mathrm{~d}, J=7.9 \mathrm{~Hz}, 2 \mathrm{H}), 7.53-$ $7.45(\mathrm{~m}, 2 \mathrm{H}), 7.40-7.28(\mathrm{~m}, 2 \mathrm{H}), 2.66(\mathrm{~s}, 3 \mathrm{H}), 2.62(\mathrm{~s}, 9 \mathrm{H})$.

${ }^{13} \mathrm{C}$ NMR (500 MHz, Acetone-d 6 ) $\delta 163.84,163.78,159.31,159.20,158.85,158.73,156.21$, $143.51,142.96,141.15,140.49,139.04,137.78,137.67,133.45,132.06,131.67,131.57,131.33$ $130.83,129.97,129.84,128.95,128.76,128.14,127.36,127.20,1126.24,126.09,126.00,125.73$ $123.84,123.62,123.05,120.40,109.77,25.21,25.16,25.04 .25 .21,25.16,25.04$.

HR-MS (ESI+): Calcd for $\mathrm{C}_{59} \mathrm{H}_{39} \mathrm{BrCuN}_{8} \mathrm{O}_{2}\left(\left[\mathrm{M}-\mathrm{BF}_{4}\right]^{+}\right): m / z$ 1033.17 Found: $m / z=1033.17$

\section{Synthesis of water oxidation catalyst (WOC).}

$[(\text { bpy }) \mathrm{Cu}(\mu-\mathrm{OH})]_{2}\left(\mathrm{SO}_{4}\right),(\boldsymbol{W O C}) . \mathrm{CuSO}_{4} \cdot 5 \mathrm{H}_{2} \mathrm{O}(2.49 \mathrm{~g}, 10.0 \mathrm{mmol})$ in $\mathrm{MeOH}(30 \mathrm{~mL})$ and 2,2'bipyridine $(1.56 \mathrm{~g}, 10.0 \mathrm{mmol})$ were combined and the solution was stirred for 4 hours at room temperature to yield a sky-blue solid of $\left[\mathrm{Cu}(\mathrm{bpy}) \mathrm{SO}_{4}\right] \cdot 2 \mathrm{H}_{2} \mathrm{O}$. The precipitates were filtered and dried in a vacuum oven at $60{ }^{\circ} \mathrm{C}$ for 2 hours. The obtained solid (ca. $2 \mathrm{~g}$ ) was then dispersed in water and sodium hydroxide $(0.11 \mathrm{M}, 52.6 \mathrm{~mL})$ was added slowly with continuous stirring and the temperature was increased from room temperature to $100{ }^{\circ} \mathrm{C}$. The resulting solution was cooled slowly to yield blue crystals of the crude product $(1.10 \mathrm{~g})$. The crystals were collected using filtration and washed with diethyl ether. The obtained salt was characterized by UV-Vis $\left(\lambda_{\max }=\right.$ $620 \mathrm{~nm}$, Figure S7) spectroscopy. 


\section{Device Fabrication}

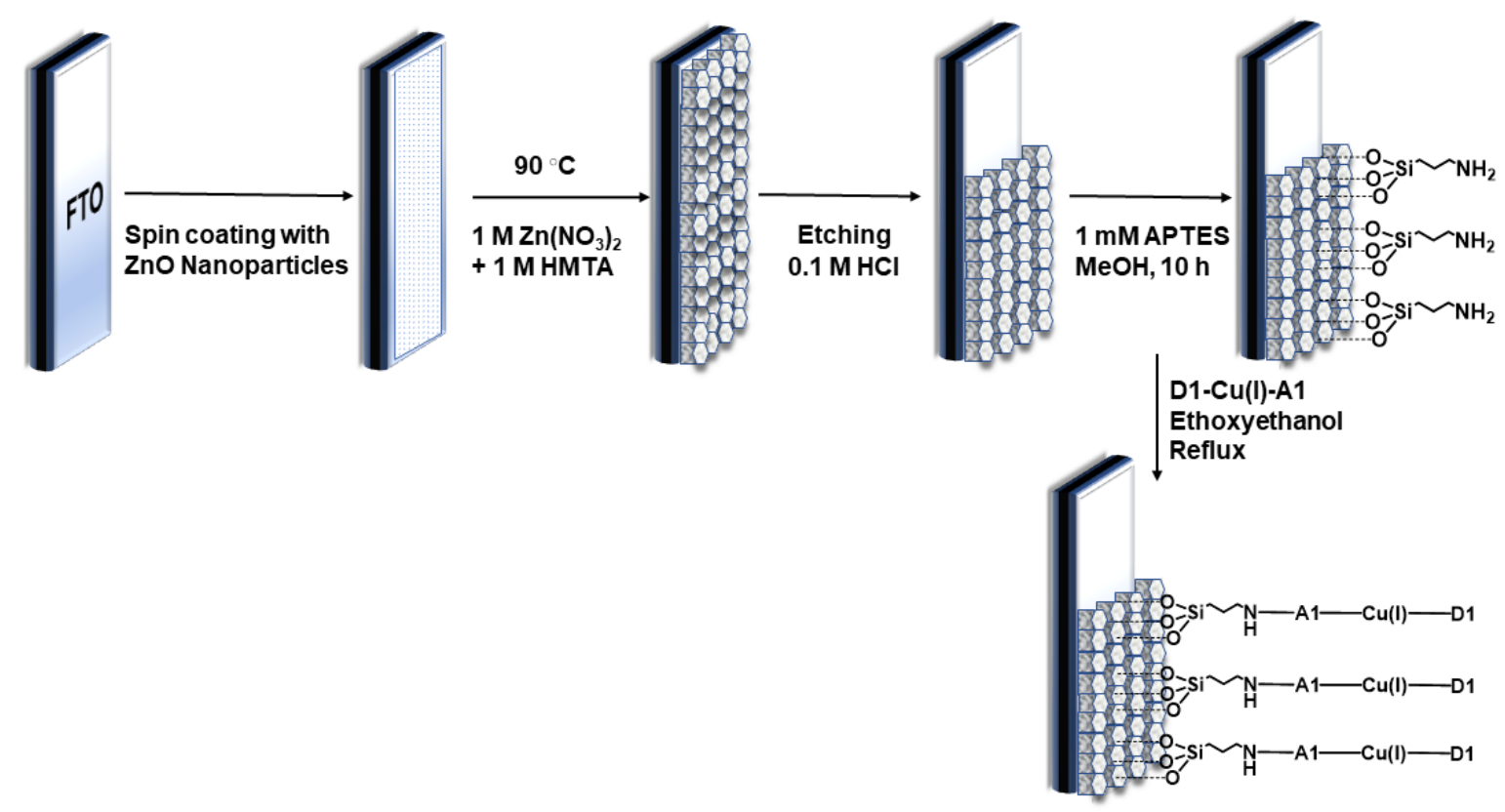

Scheme S3. General scheme for the preparation of ZnO NWs|A1-C-D1 photoanodes.

Zinc oxide nanowires (ZnO NWs). ZnO NWs were synthesized on fluorine doped tin oxide (FTO) on a glass substrate according to a modification of a previously published procedure. ${ }^{5,6}$ FTO slides were cleaned by successively sonicating with $1 \mathrm{M} \mathrm{HCl}$ solution, deionized water, and with ethanol for 10 minutes each and then dried in an oven at $100{ }^{\circ} \mathrm{C}$ for 3 hours. These films were spin coated with $1 \% \mathrm{w} / \mathrm{w} \mathrm{ZnO}$ nanoparticle suspension in ethanol (2 drops) at $500 \mathrm{rpm}$ for $5 \mathrm{~s}(2 \times)$. Afterward, the pre-treated FTO electrode was immersed in an aqueous solution containing $25 \mathrm{mM}$ zinc nitrate hexahydrate and $25 \mathrm{mM} \mathrm{HMTA}$ at $90{ }^{\circ} \mathrm{C}$ for $3 \mathrm{~h}$. After wire growth, the films were rinsed with Milli-Q water and ethanol and the electrode was dried in an oven at $50{ }^{\circ} \mathrm{C}$. The nanowires were characterized using scanning electron microscopy (SEM) and powder X-ray diffraction (PXRD) techniques. The PXRD pattern of surface shows oriented growth which was 
further confirmed by SEM analysis. SEM images revealed hexagonal nanorods having lengths of 1.5-2.0 $\mu \mathrm{m}$ (Figure S2), further confirmed by profilometry results.

Photoelectrode fabrication. $\mathrm{ZnO} \mathrm{NW}$ electrodes were immersed in a methanol solution containing 1\% APTES for 10 hours at room temperature, removed and rinsed with methanol $(3 \times)$ and then dried in oven at $60{ }^{\circ} \mathrm{C}$. This silanized electrode was then refluxed in a $1 \mathrm{mM}$ solution of D1-C-A1 or C-A1 in 2-ethoxyethanol for 6 hours. The ZnO NWs $\mid$ A1-C-D1 or ZnO NWs $\mid$ A1-C electrode was then washed with ethanol and $\mathrm{CH}_{2} \mathrm{Cl}_{2}$ and dried in an oven at $90{ }^{\circ} \mathrm{C}$ for 3 hours. The resulting photoelectrode was characterized using diffuse reflectance UV-Vis, IR and SEM.

Collector-Generator Fabrication. The upper corner of an as-fabricated ZnO NWs|A1-C-D1 or ZnO NWs $\mid$ A1-C electrode and the opposite upper corner of an unfunctionalized clean FTO glass electrode $(10 \mathrm{~mm} \times 15 \mathrm{~mm})$ was removed with a diagonal cut to approximately $8-10 \mathrm{~mm}$ down from the top along the long edge. Copper wires were bonded to the remaining upper corner of the electrodes using conductive silver epoxy. These two working electrodes were epoxied (conventional, nonconductive) together using thin pieces of $1 \mathrm{~mm}$ microscopic slides along the edges of the two electrodes with conductive side of both the electrodes facing each other. ${ }^{3}$ 


\section{Results and Discussion}

\section{Differential Pulse Voltammetry on D1-C-A1}

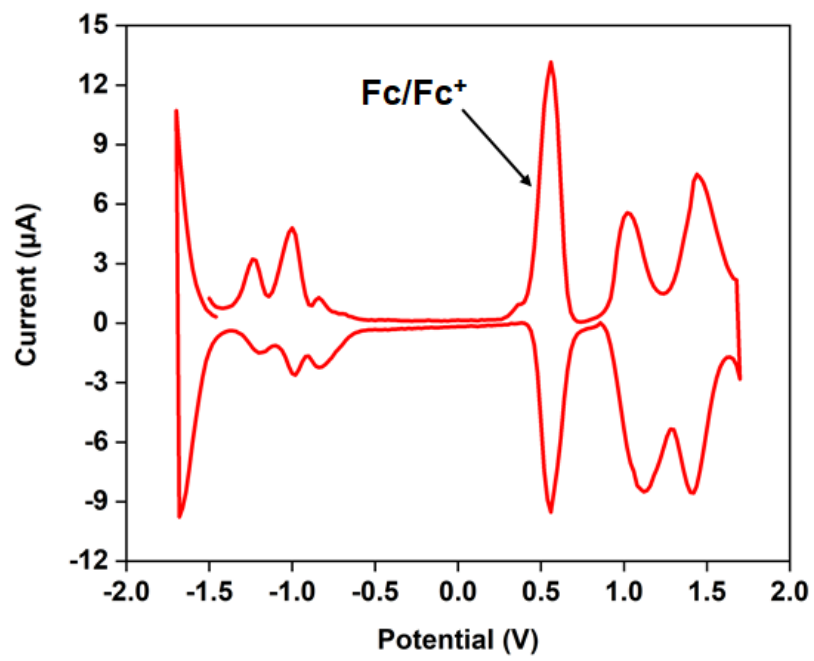

Figure S1. Differential pulse voltammogram of D1-C-A1 with ferrocene as internal standard conducted using a three-electrode setup with a pulse height of $20 \mathrm{mV}$, pulse width of $50 \mathrm{~ms}$, pulse period of $200 \mathrm{~ms}$ and pulse increment of $20 \mathrm{mV}$. Recorded in $0.1 \mathrm{Mn}$-[Bu $4 \mathrm{~N}] \mathrm{PF}_{6}$ in $\mathrm{CH}_{2} \mathrm{Cl}_{2}, 100$ $\mathrm{mV} / \mathrm{s}, 3 \mathrm{~mm}$ Pt button working electrode (WE), a Pt wire as counter electrode (CE), Ag wire pseudoreference electrode $(\mathrm{RE})$, and ferrocene $(\mathrm{Fc})$ as an internal standard. 


\section{Device characterization}

A.

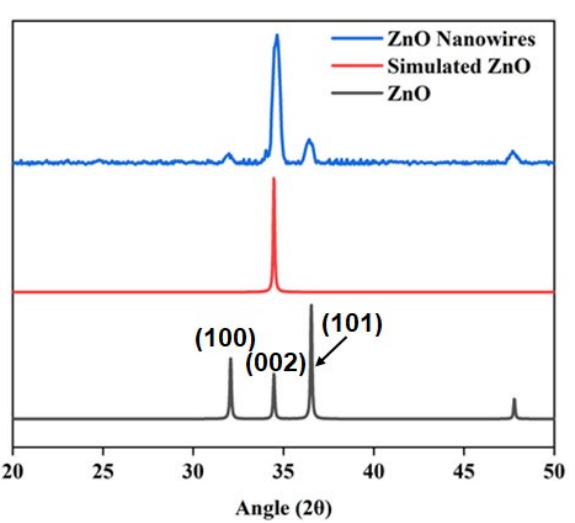

B.

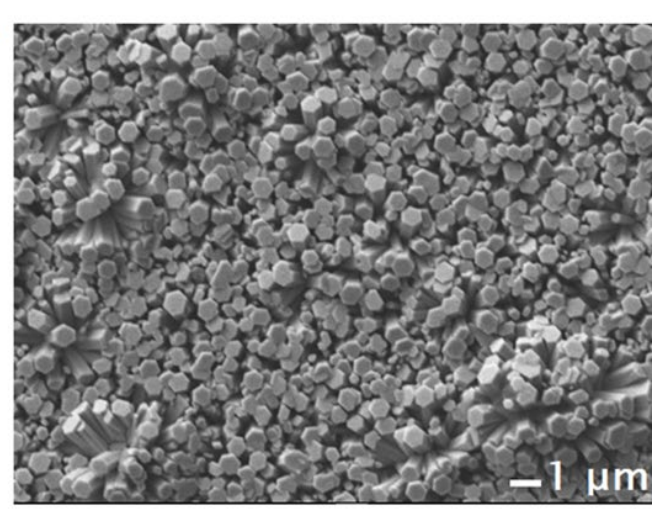

C.

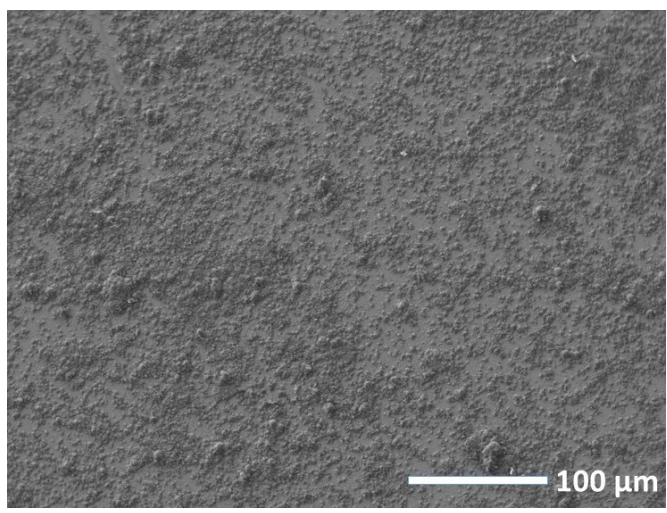

D.
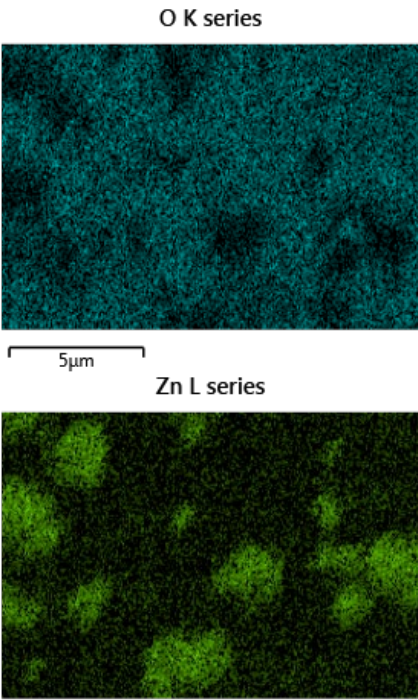

$5 \mu \mathrm{m}$

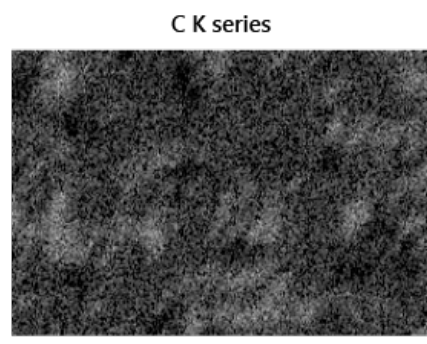

$\stackrel{5 \mu m}{5}$ Si K series
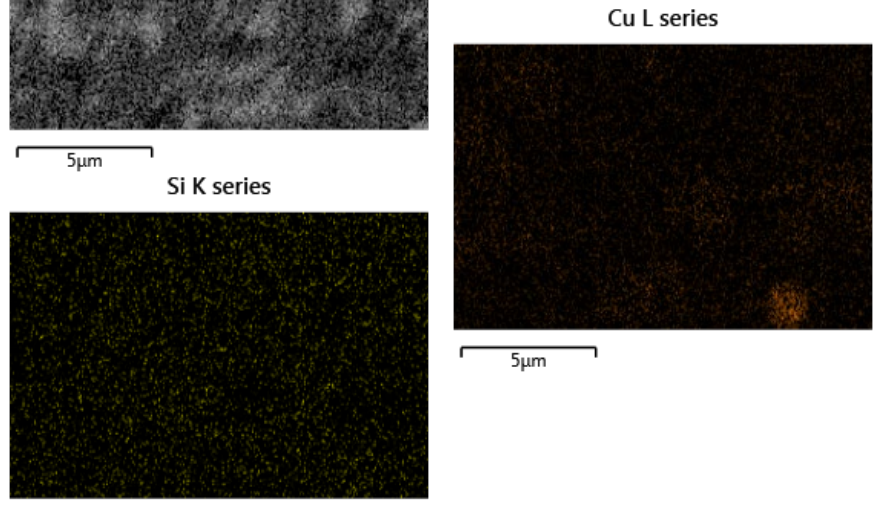

5 pum

$5 \mu m$

Figure S2. A) Powder $\mathrm{X}$-Ray diffraction pattern showing the (002) phase of $\mathrm{ZnO}$ nanowires grown onto FTO slide. B) Scanning electron micrograph of as-grown nanowires. C) Scanning electron micrograph of ZnO NWs $\mid$ A1-C-D1. D) EDS elemental analysis of $\mathbf{Z n O}$ NWs $\mid$ A1-C-D1. 


\section{Loading Calculations}

A.

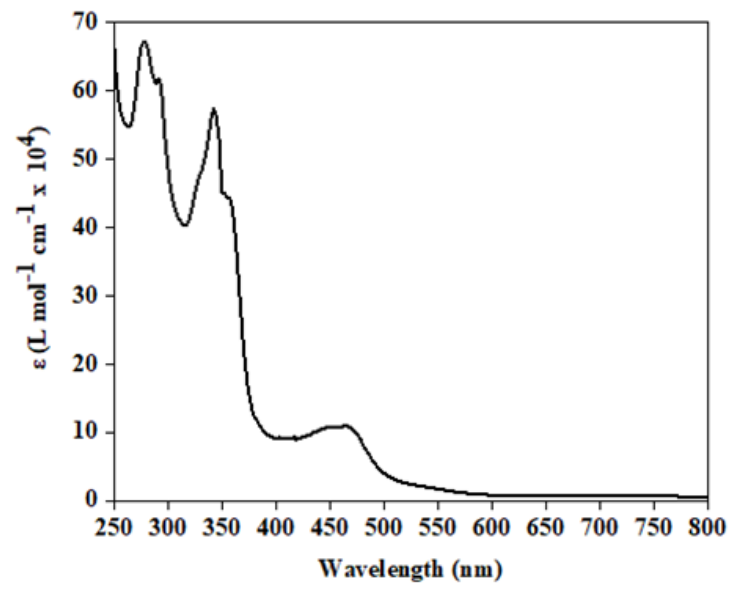

B.

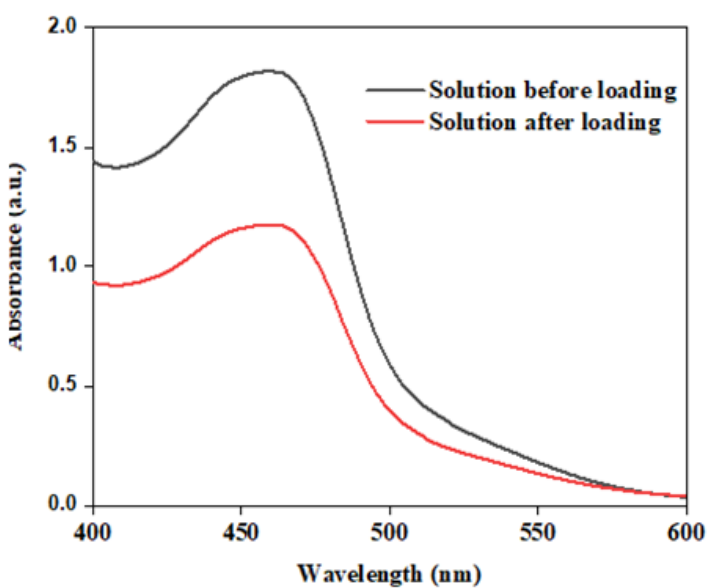

Figure S3. A) UV-Vis spectra of D1-C-A1 in ethoxyethanol to calculate molar absorptivity constant in this solvent $\left(\varepsilon=10710 \mathrm{~L} \mathrm{~mol}^{-1} \mathrm{~cm}^{-1}\right.$ at $\left.\lambda_{\max }=460 \mathrm{~nm}\right)$. B) UV-Vis spectra of the solution of D1-C-A1 before and after (16 hrs) loading onto APTES functionalized ZnO NW surface.

\section{Overlaid UV-Vis Spectrum of D1-C-A1 and Photoelectrode}

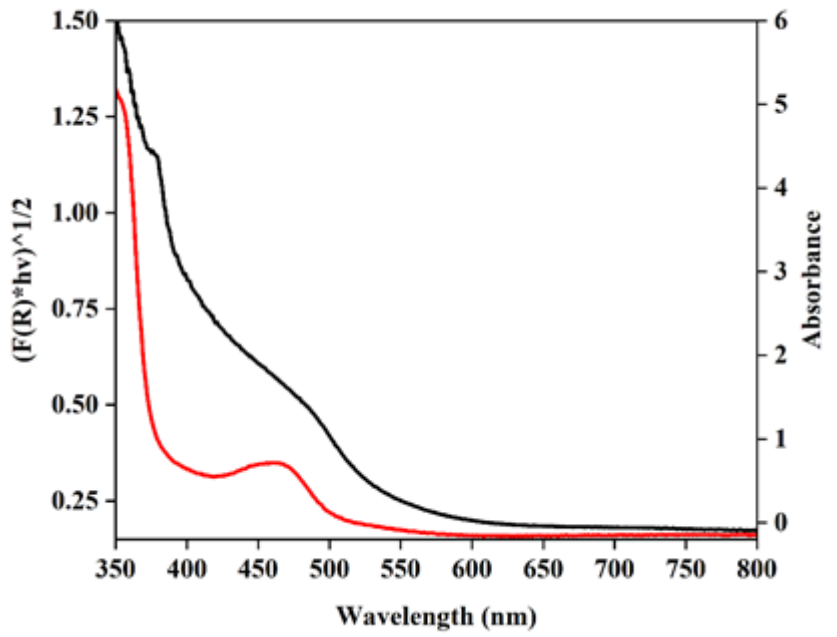

Figure S4. Overlaid room temperature UV-Vis spectrum of D1-C-A1 in $\mathrm{CH}_{2} \mathrm{Cl}_{2}$ (red) and diffuse reflectance spectrum (DRS) of ZnO NWs|D1-C-A1 (black). 


\section{Photoelectrochemical Studies}

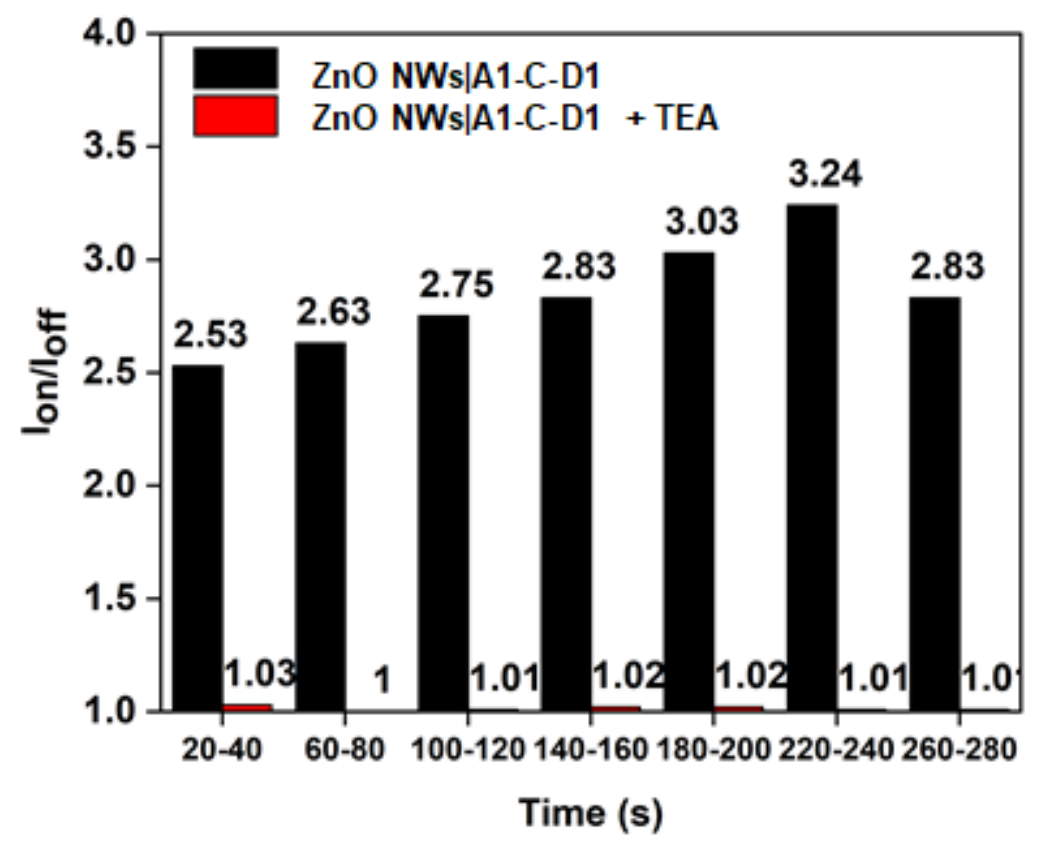

Figure S5. Photocurrent ratios of photocurrent at the beginning of light on versus at the end of light on in the absence (black) and presence (red) of triethylamine. 


\section{Energy level diagram}

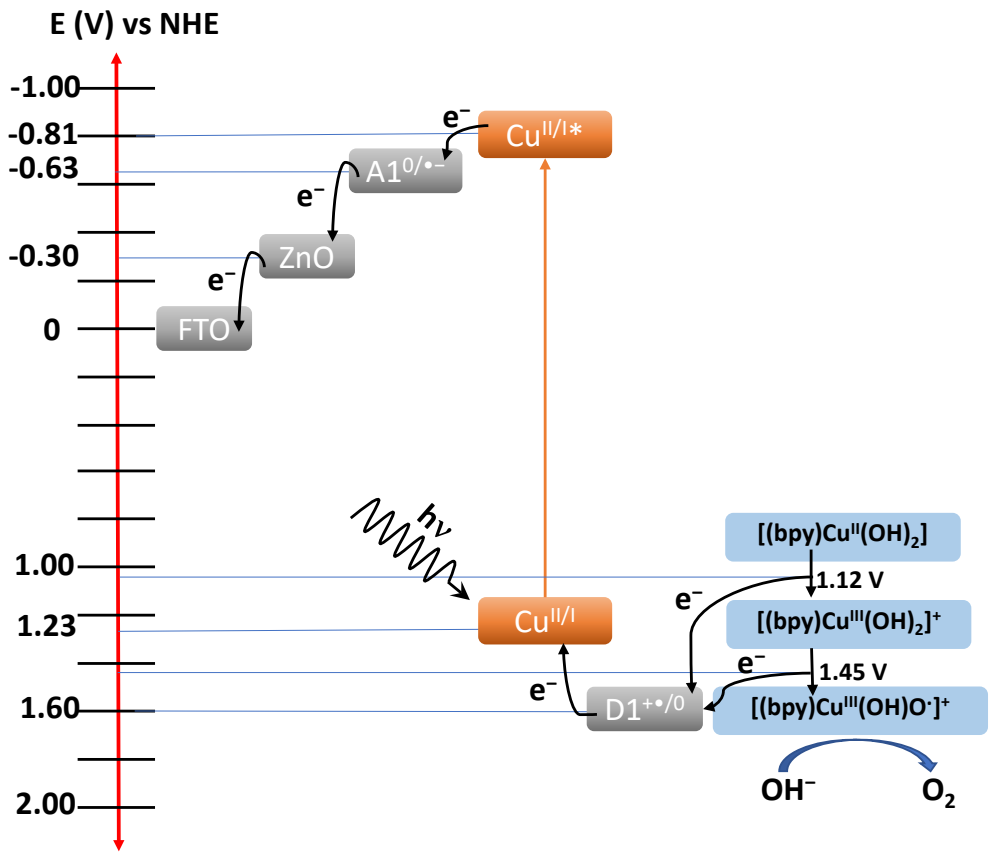

Scheme S4. Proposed energy level diagram for the reported system illustrating the relationship between relevant excited states and redox species of both the catalyst and chromophore bound to the surface. $\mathrm{ZnO}$ conduction band position adapted from Tamirat et al. ${ }^{7}$

\section{Experimental Generator-Collector Setup}

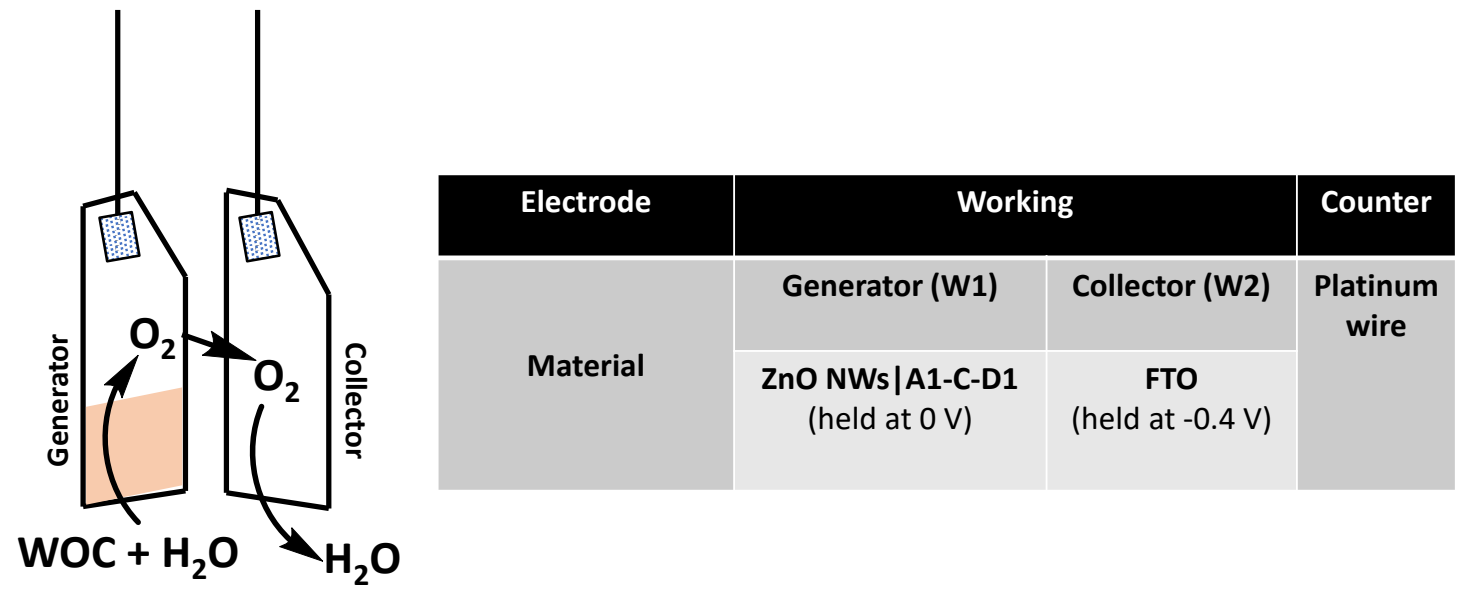

Scheme S5. A representation of the photoelectrochemical generator-collector setup used to test for $\mathrm{O}_{2}$ evolution with corresponding biases (all potentials vs. $\mathrm{Ag} / \mathrm{AgCl}$ ). 

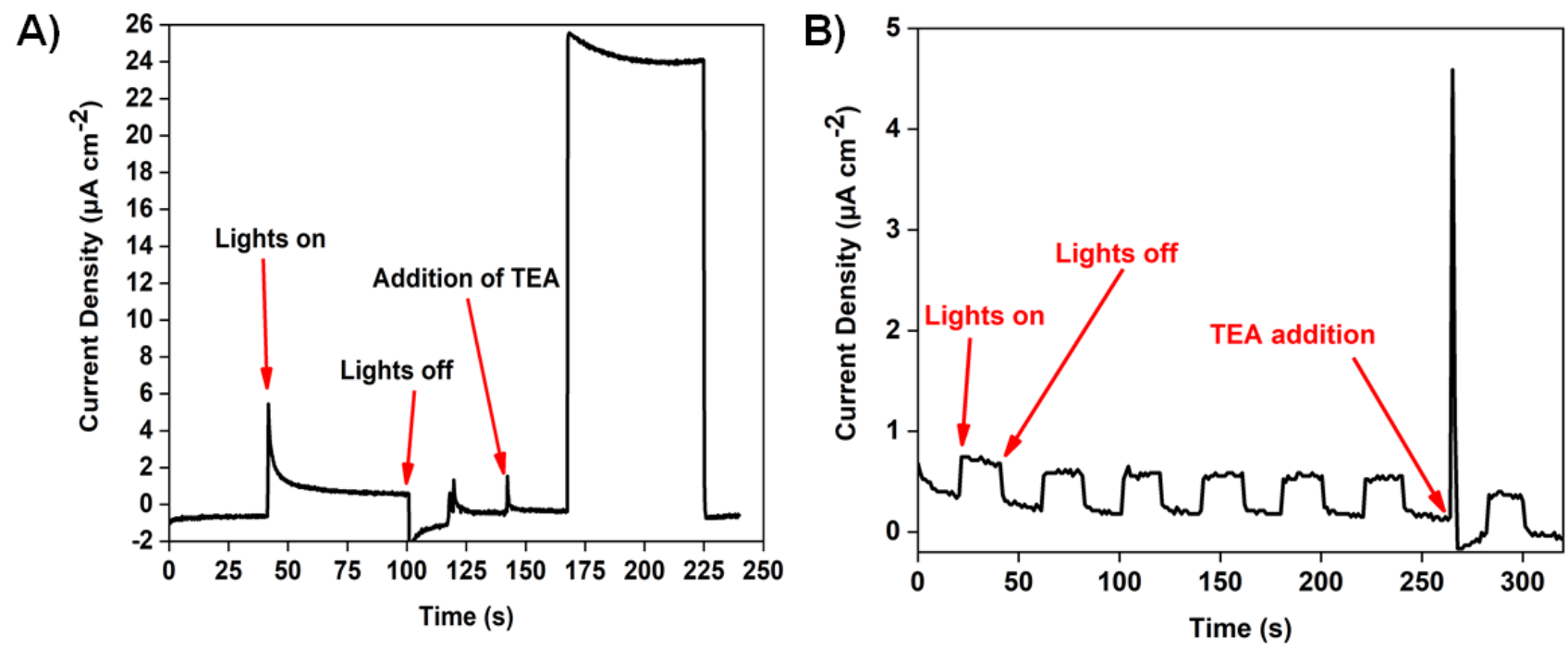

Figure S6. A) Chronoamperometry experiments of ZnO NWs|A1-C-D1 with and without the addition of triethylamine as sacrificial electron donor. B) Chopped-light chronoamperometry experiments of $\mathbf{Z n O} \mathbf{N W s} \mid \mathbf{A 1}$-C without and with the addition of triethylamine as a sacrificial electron donor in $1 \mathrm{M} \mathrm{Na}_{2} \mathrm{SO}_{4} / \mathrm{NaOH}$ solution adjusted to $\mathrm{pH} 12$; $\mathrm{RE}$ : $\mathrm{Ag} / \mathrm{AgCl}(3 \mathrm{M} \mathrm{KCl}), \mathrm{CE}$ : Pt Wire.

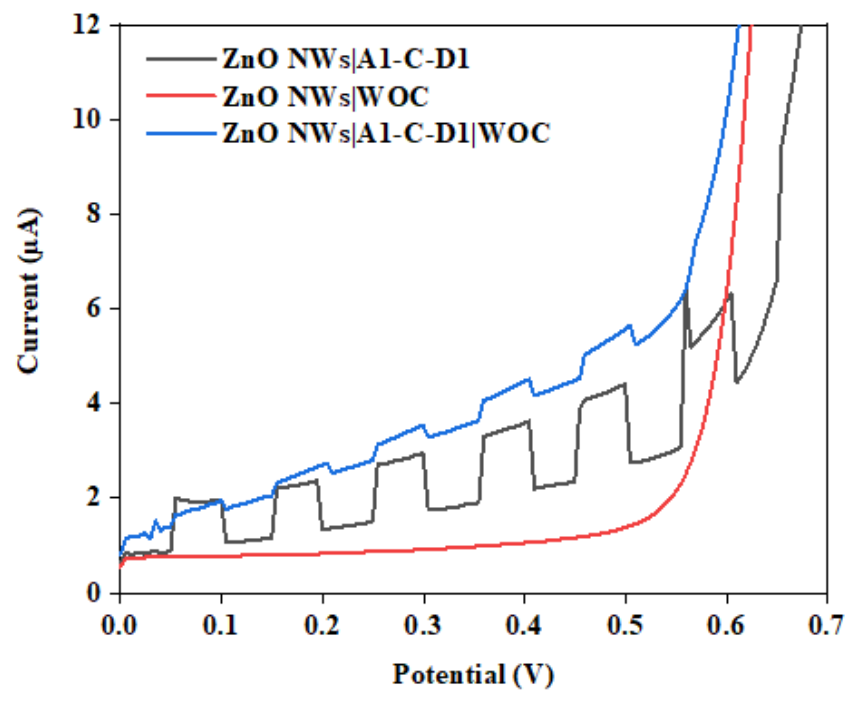

Figure S7. Chopped white light linear sweep voltammograms in the presence of WOC and in the absence of WOC. ZnO NWs $\mid$ A1-C-D1 (black), ZnO NWs $\mid$ WOC (red) and ZnO NWs $\mid$ A1-CD1|WOC (blue) film. RE: $\mathrm{Ag} / \mathrm{AgCl}, \mathrm{CE}$ : Pt wire, $0.1 \mathrm{M} \mathrm{Na}_{2} \mathrm{SO}_{4} / \mathrm{NaOH}(\mathrm{pH} 12)$, scan rate: $5 \mathrm{mV}$ $\mathrm{s}^{-1}$. 


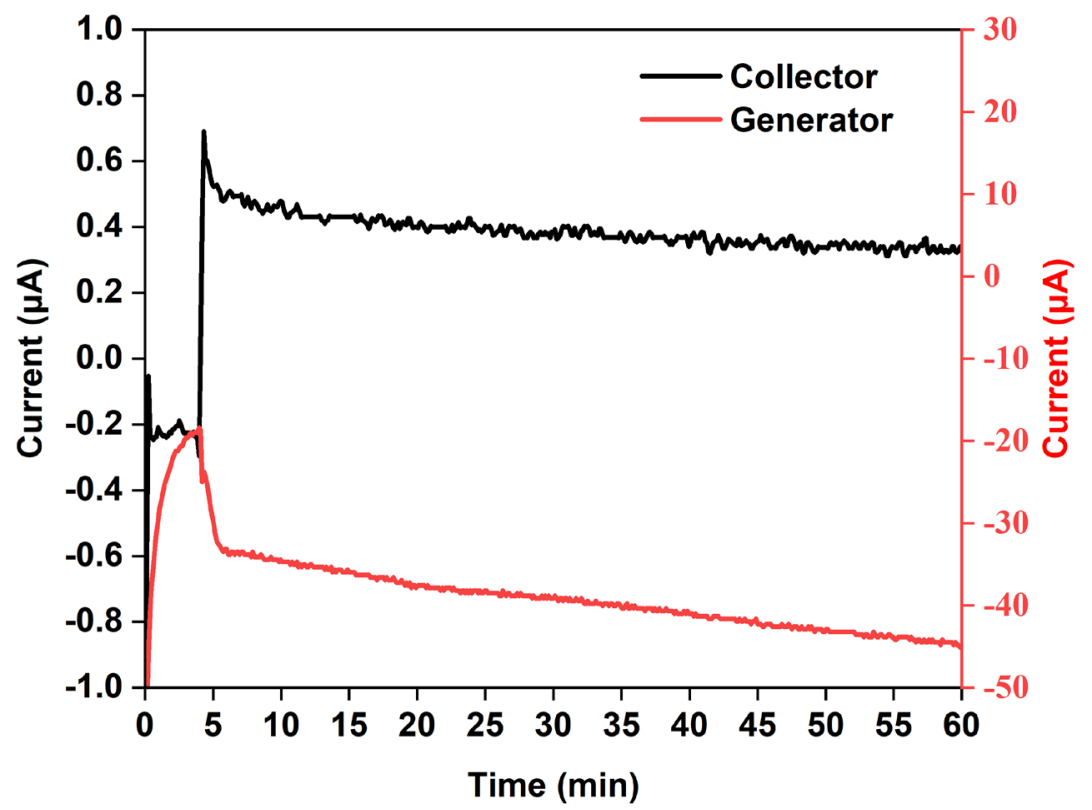

Figure S8. Stability test on collector-generator dual electrode experiments on ZnO NWs|A1-CD1 film with WOC catalyst under one hour of irradiation. The generator electrodes were held at no bias and illuminated using white light. The collector electrode for each experiment was held at an applied bias of $-0.40 \mathrm{~V}$. (Conditions: $1.0 \mathrm{M} \mathrm{Na}_{2} \mathrm{SO}_{4}$ at $\mathrm{pH} 12, \mathrm{RE}=\mathrm{Ag} / \mathrm{AgCl} ; \mathrm{CE}=\mathrm{Pt}$ wire).

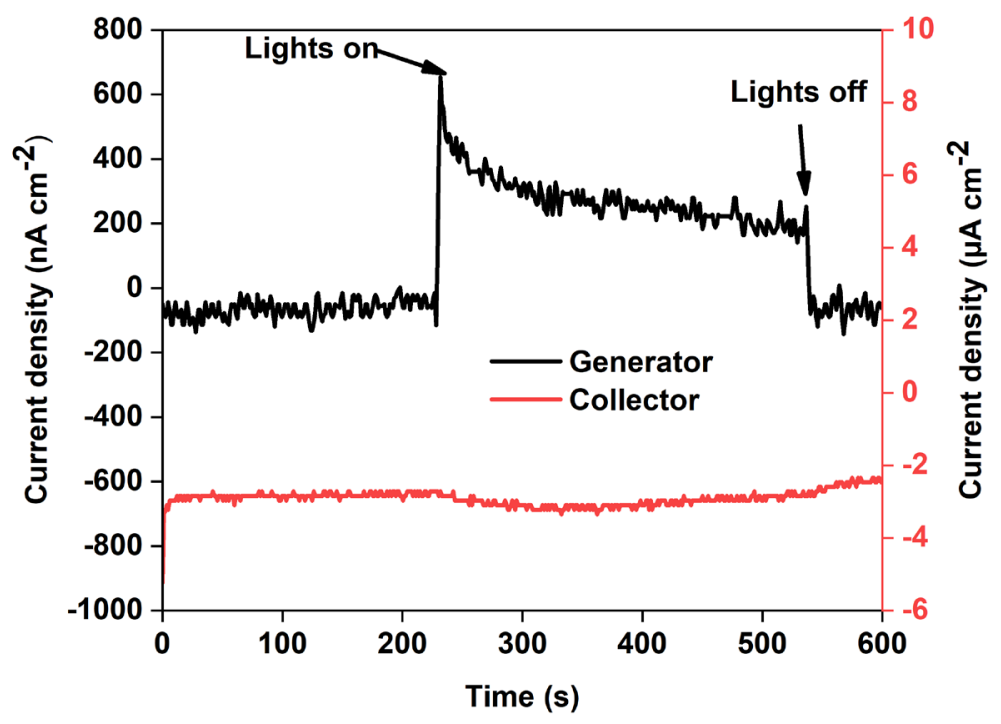

Figure S9. Collector-generator dual electrode experiments on ZnO NWs $\mid$ A1-C film with WOC catalyst. The generator electrode was held at no bias and illuminated using white light. The 
collector electrode was held at an applied bias of $-0.40 \mathrm{~V}$. (Conditions: $1.0 \mathrm{M} \mathrm{Na}_{2} \mathrm{SO}_{4}$ at $\mathrm{pH} 12$, $\mathrm{RE}=\mathrm{Ag} / \mathrm{AgCl} ; \mathrm{CE}=\mathrm{Pt}$ wire) .

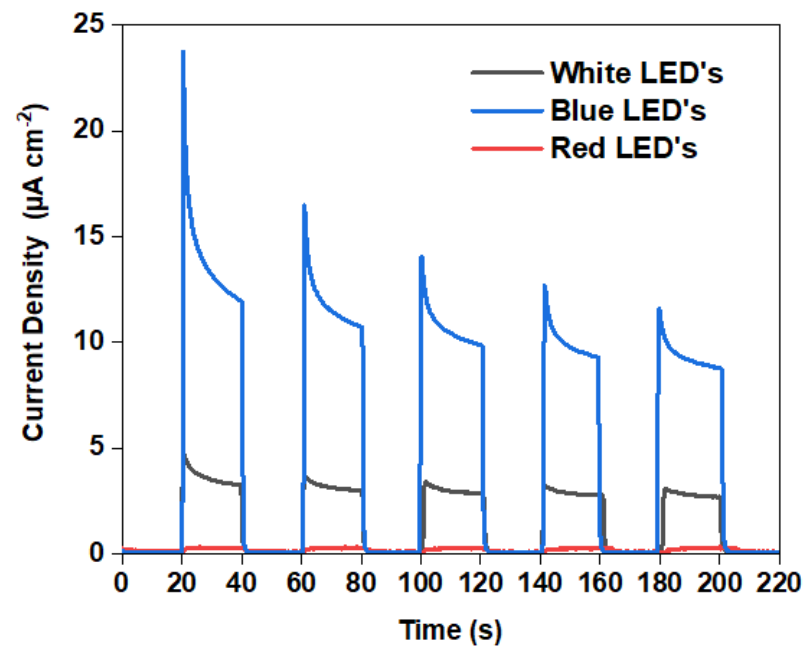

Figure S10. Chopped light chronoamperometry experiments of ZnO NWs $\mid$ A1-C-D1 using white, blue and red LEDs in $1 \mathrm{M} \mathrm{Na}_{2} \mathrm{SO}_{4} / \mathrm{NaOH}$ (pH 12); RE: $\mathrm{Ag} / \mathrm{AgCl}, \mathrm{CE}$ : Pt Wire.

\section{WOC characterization}

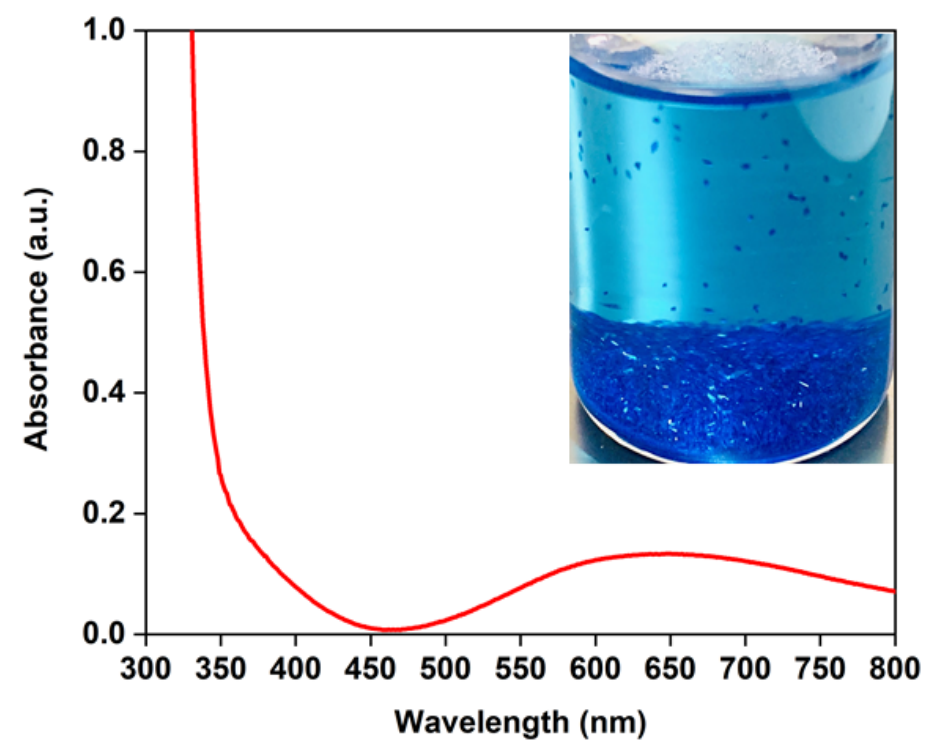

Figure S11. UV-Vis absorbance spectra of WOC in water and a digital photograph of as-grown WOC crystals (inset). 


\section{DFT Calculations}

The calculations were carried out with Gaussian $16^{8}$ using the B3PW91 functional ${ }^{9}$ with $\operatorname{dgdzvp} p^{10,11}$ as basis set. The optimizations were conducted without symmetry constraint, and frequency calculations were made to confirm reaching the energy minima. GaussView $5^{12}$ and GaussSum $3.0^{13}$ were used for data analysis, visualization and plots. All calculations were conducted for gaseous phase complexes.

Table S1. Contributions to MOs for D1-C.

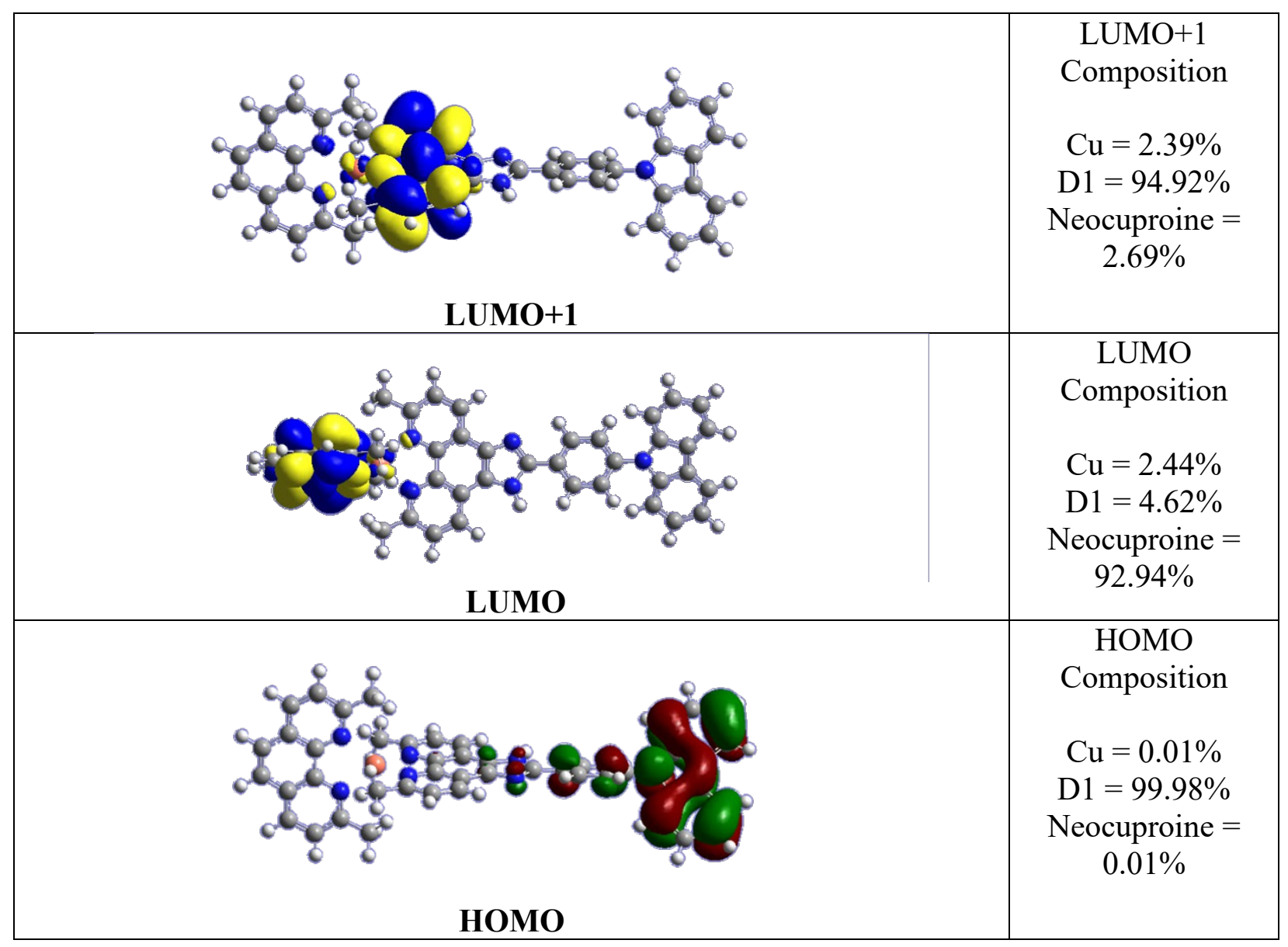




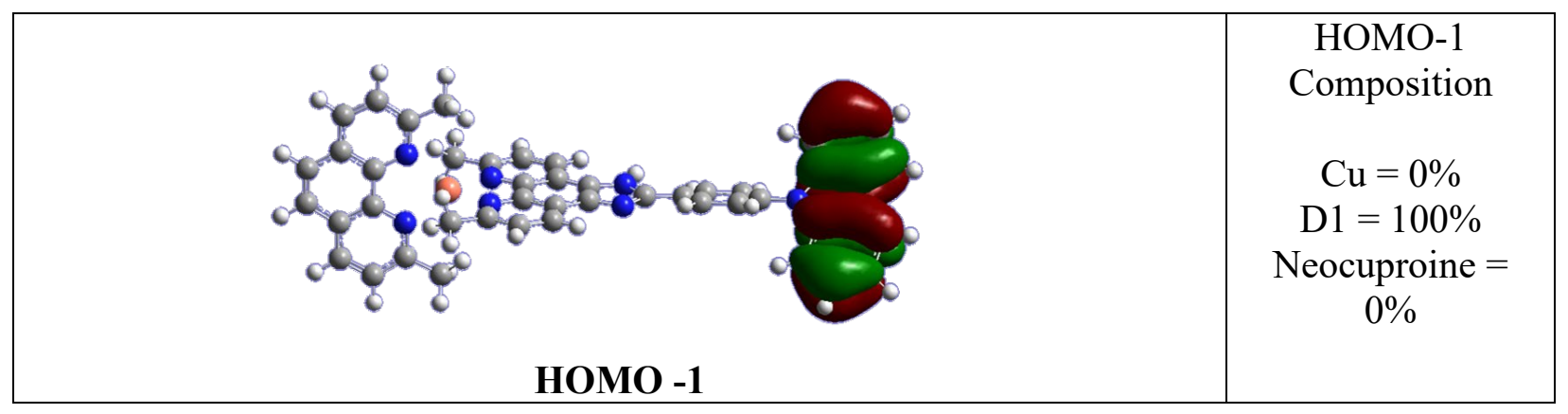

Table S2. Contributions to MOs for D1-C.

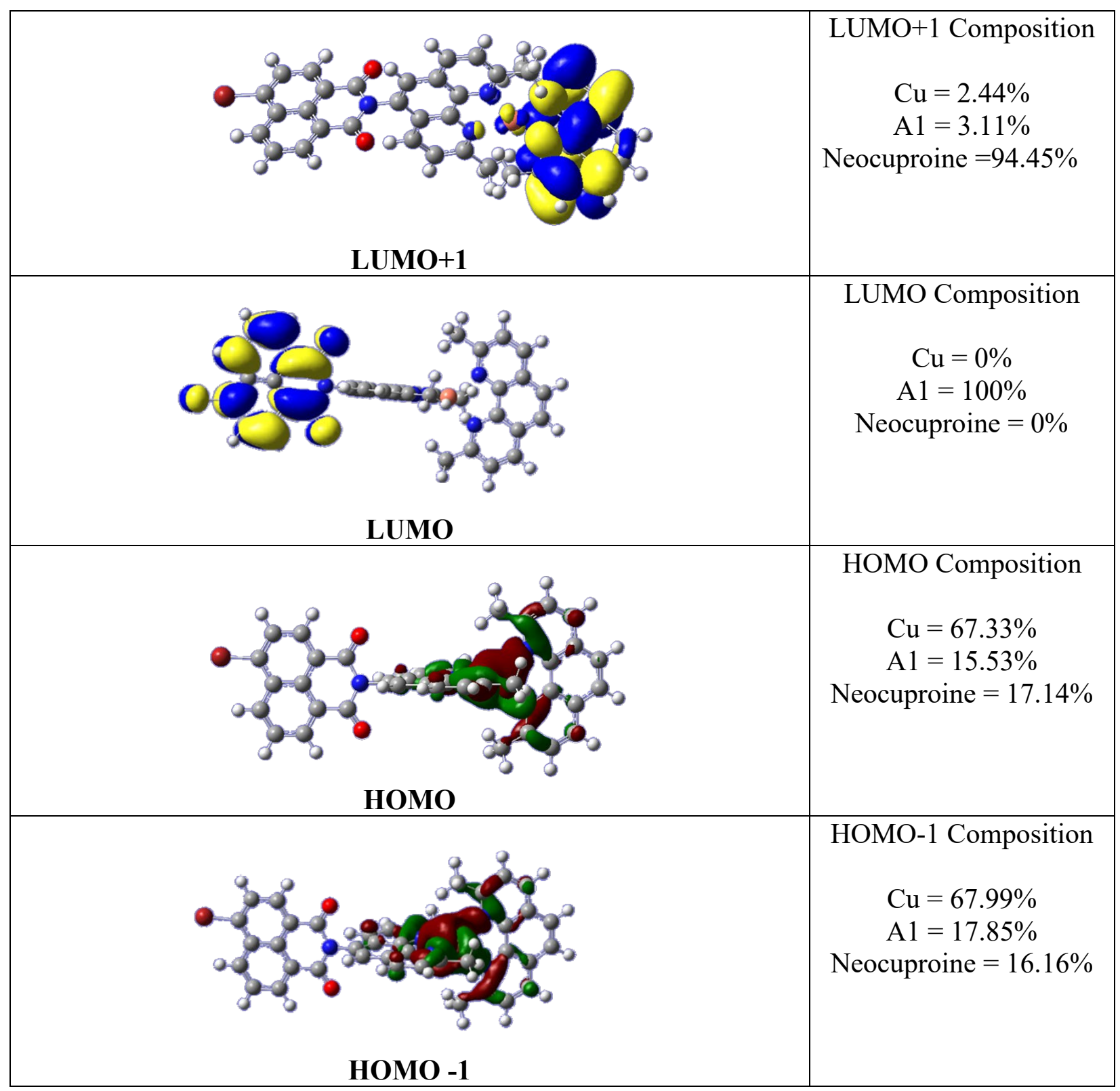


Table S3. Contributions to MOs for D1-C-A1.

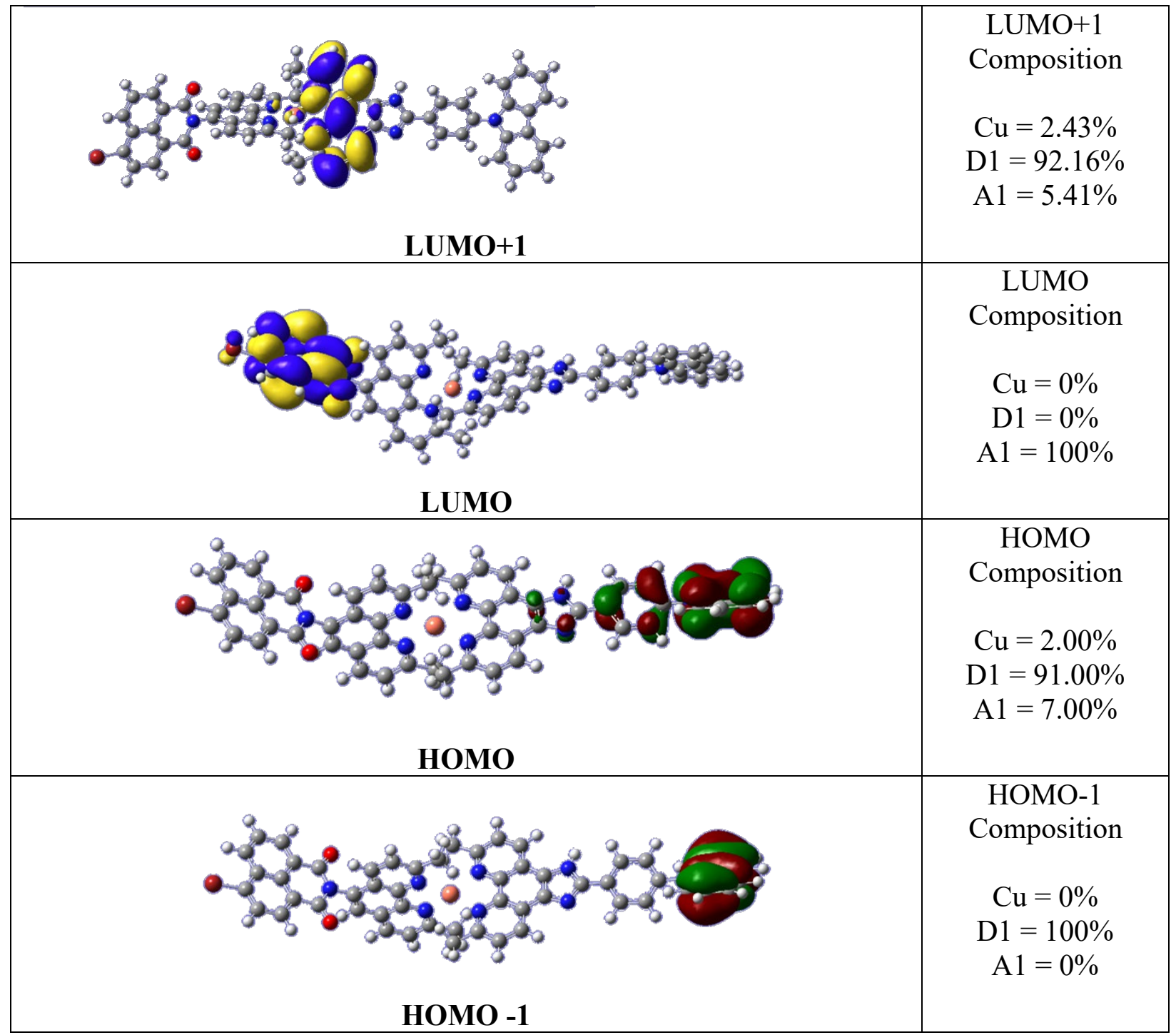

Table S4. Atomic coordinates of the optimized geometry of D1-C-A1.

\begin{tabular}{|c|c|c|c|c|c|c|c|c|c|}
\hline \multirow{2}{*}{ Center } & \multirow{2}{*}{ Symbol } & \multicolumn{3}{|c|}{ Coordinates $(\AA)$} & \multirow{2}{*}{ Center } & \multirow{2}{*}{ Symbol } & \multicolumn{3}{|c|}{ Coordinates $(\AA)$} \\
\hline & & $\mathbf{X}$ & $\mathbf{Y}$ & $\mathbf{Z}$ & & & $\mathbf{X}$ & $\mathbf{Y}$ & $\mathbf{Z}$ \\
\hline 1 & $\mathrm{Cu}$ & -0.872915 & -0.704985 & 0.519739 & 56 & $\mathrm{O}$ & -7.425392 & -1.983868 & -1.503691 \\
\hline 2 & $\mathrm{C}$ & 1.880215 & 0.066177 & 0.768076 & 57 & $\mathrm{O}$ & -7.471952 & 1.277622 & 1.685148 \\
\hline 3 & $\mathrm{C}$ & 0.620377 & 1.370938 & 2.228882 & 58 & $\mathrm{~N}$ & -7.480739 & -0.371456 & 0.108109 \\
\hline 4 & $\mathrm{C}$ & 1.882404 & -0.98185 & -0.239628 & 59 & $\mathrm{C}$ & -9.451262 & -0.743212 & -1.302628 \\
\hline 5 & $\mathrm{C}$ & 3.084249 & 0.691697 & 1.15971 & 60 & $\mathrm{C}$ & -10.122346 & 0.301379 & -0.617805 \\
\hline 6 & $\mathrm{C}$ & 1.78637 & 2.036382 & 2.666779 & 61 & $\mathrm{C}$ & -10.082954 & -1.441126 & -2.316617 \\
\hline 7 & $\mathrm{C}$ & 3.092739 & -1.396136 & -0.856079 & 62 & $\mathrm{C}$ & -9.473325 & 1.01682 & 0.418269 \\
\hline
\end{tabular}




\begin{tabular}{|c|c|c|c|c|c|c|c|c|c|}
\hline 8 & $\mathrm{C}$ & 4.298466 & 0.261763 & 0.535968 & 63 & $\mathrm{C}$ & -11.463569 & 0.629681 & -0.986307 \\
\hline 9 & $\mathrm{C}$ & 3.014023 & 1.701257 & 2.137311 & 64 & $\mathrm{C}$ & -11.403377 & -1.119388 & -2.678005 \\
\hline 10 & $\mathrm{H}$ & 1.702404 & 2.813669 & 3.420572 & 65 & $\mathrm{H}$ & -9.541291 & -2.236047 & -2.820613 \\
\hline 11 & $\mathrm{C}$ & 3.007376 & -2.416098 & -1.824485 & 66 & $\mathrm{C}$ & -10.134358 & 2.036391 & 1.078902 \\
\hline 12 & $\mathrm{C}$ & 0.618552 & -2.505678 & -1.4739 & 67 & $\mathrm{C}$ & -12.099848 & 1.687457 & -0.274058 \\
\hline 13 & $\mathrm{H}$ & 3.925743 & 2.199462 & 2.453516 & 68 & $\mathrm{C}$ & -12.07951 & -0.107301 & -2.028731 \\
\hline 14 & $\mathrm{C}$ & 1.779686 & -2.964895 & -2.129441 & 69 & $\mathrm{H}$ & -11.893636 & -1.672513 & -3.473647 \\
\hline 15 & $\mathrm{H}$ & 3.899156 & -2.775083 & -2.331978 & 70 & $\mathrm{C}$ & -11.453063 & 2.3747 & 0.733769 \\
\hline 16 & $\mathrm{H}$ & 1.697679 & -3.7525 & -2.872194 & 71 & $\mathrm{H}$ & -9.618945 & 2.571833 & 1.870731 \\
\hline 17 & $\mathrm{~N}$ & 0.679919 & 0.412449 & 1.302274 & 72 & $\mathrm{H}$ & -13.098209 & 0.134087 & -2.314418 \\
\hline 18 & $\mathrm{~N}$ & 0.687429 & -1.53891 & -0.555776 & 73 & $\mathrm{H}$ & -11.96258 & 3.175377 & 1.259545 \\
\hline 19 & $\mathrm{C}$ & -0.735855 & -3.066278 & -1.793581 & 74 & $\mathrm{Br}$ & -13.878748 & 2.193894 & -0.691649 \\
\hline 20 & $\mathrm{H}$ & -0.663128 & -4.014542 & -2.329947 & 75 & $\mathrm{C}$ & 4.282335 & -0.738955 & -0.431701 \\
\hline 21 & $\mathrm{H}$ & -1.312489 & -3.218836 & -0.877602 & 76 & $\mathrm{C}$ & 6.340461 & 0.014071 & -0.063075 \\
\hline 22 & $\mathrm{H}$ & -1.299426 & -2.365845 & -2.419489 & 77 & $\mathrm{H}$ & 5.973428 & -1.561417 & -1.451982 \\
\hline 23 & $\mathrm{C}$ & -0.723644 & 1.701202 & 2.809223 & 78 & $\mathrm{~N}$ & 5.599068 & -0.881498 & -0.805453 \\
\hline 24 & $\mathrm{H}$ & -1.508961 & 1.567589 & 2.061641 & 79 & $\mathrm{~N}$ & 5.568573 & 0.716315 & 0.753079 \\
\hline 25 & $\mathrm{H}$ & -0.949099 & 1.033802 & 3.64865 & 80 & $\mathrm{C}$ & 7.789117 & 0.152353 & -0.173729 \\
\hline 26 & $\mathrm{H}$ & -0.757093 & 2.726885 & 3.183312 & 81 & $\mathrm{C}$ & 8.529496 & -0.449647 & -1.203229 \\
\hline 27 & $\mathrm{C}$ & -3.528335 & -1.461868 & 1.282246 & 82 & $\mathrm{C}$ & 8.472963 & 0.91934 & 0.783366 \\
\hline 28 & $\mathrm{C}$ & -2.041532 & -2.696239 & 2.574199 & 83 & $\mathrm{C}$ & 9.90794 & -0.293109 & -1.275999 \\
\hline 29 & $\mathrm{C}$ & -3.719781 & -0.472567 & 0.251927 & 84 & $\mathrm{H}$ & 8.039085 & -1.01683 & -1.991538 \\
\hline 30 & $\mathrm{C}$ & -4.655925 & -2.052455 & 1.890226 & 85 & $\mathrm{C}$ & 9.850797 & 1.067528 & 0.721561 \\
\hline 31 & $\mathrm{C}$ & -3.119878 & -3.33105 & 3.232746 & 86 & $\mathrm{H}$ & 7.907667 & 1.379804 & 1.587455 \\
\hline 32 & $\mathrm{C}$ & -5.027338 & -0.111278 & -0.138322 & 87 & $\mathrm{C}$ & 10.585548 & 0.463862 & -0.31007 \\
\hline 33 & $\mathrm{C}$ & -5.967919 & -1.669144 & 1.476246 & 88 & $\mathrm{H}$ & 10.464401 & -0.732076 & -2.098383 \\
\hline 34 & $\mathrm{C}$ & -4.416177 & -3.014191 & 2.895329 & 89 & $\mathrm{H}$ & 10.372375 & 1.6341 & 1.487064 \\
\hline 35 & $\mathrm{H}$ & -2.911476 & -4.068929 & 4.00182 & 90 & $\mathrm{~N}$ & 11.981199 & 0.619795 & -0.379134 \\
\hline 36 & $\mathrm{C}$ & -5.147655 & 0.865109 & -1.148894 & 91 & $\mathrm{C}$ & 14.05933 & 1.57956 & -0.443911 \\
\hline 37 & $\mathrm{C}$ & -6.149024 & -0.73783 & 0.50193 & 92 & $\mathrm{C}$ & 12.672717 & 1.838161 & -0.339899 \\
\hline 38 & $\mathrm{C}$ & -2.736643 & 1.003114 & -1.253062 & 93 & $\mathrm{C}$ & 14.963111 & 2.647364 & -0.451325 \\
\hline 39 & $\mathrm{H}$ & -6.830543 & -2.130268 & 1.949105 & 94 & $\mathrm{C}$ & 12.174102 & 3.140621 & -0.272518 \\
\hline 40 & $\mathrm{H}$ & -5.252788 & -3.498173 & 3.392959 & 95 & $\mathrm{C}$ & 14.475123 & 3.947302 & -0.362874 \\
\hline 41 & $\mathrm{C}$ & -4.012798 & 1.415227 & -1.698522 & 96 & $\mathrm{H}$ & 16.031816 & 2.466077 & -0.530816 \\
\hline 42 & $\mathrm{H}$ & -6.13018 & 1.180718 & -1.485782 & 97 & $\mathrm{C}$ & 13.09389 & 4.187369 & -0.280845 \\
\hline 43 & $\mathrm{H}$ & -4.085372 & 2.170886 & -2.475124 & 98 & $\mathrm{H}$ & 11.108456 & 3.344086 & -0.227673 \\
\hline 44 & $\mathrm{C}$ & -0.623209 & -3.012678 & 2.946226 & 99 & $\mathrm{H}$ & 15.165561 & 4.785998 & -0.3658 \\
\hline 45 & $\mathrm{H}$ & 0.052924 & -2.768182 & 2.124455 & 100 & $\mathrm{H}$ & 12.730768 & 5.21024 & -0.227638 \\
\hline 46 & $\mathrm{H}$ & -0.320146 & -2.421797 & 3.817996 & 101 & $\mathrm{C}$ & 14.214871 & 0.144555 & -0.547665 \\
\hline 47 & $\mathrm{H}$ & -0.506361 & -4.067216 & 3.208197 & 102 & $\mathrm{C}$ & 12.916602 & -0.415359 & -0.506498 \\
\hline 48 & $\mathrm{C}$ & -1.489844 & 1.577845 & -1.857476 & 103 & $\mathrm{C}$ & 15.327709 & -0.697025 & -0.648964 \\
\hline 49 & $\mathrm{H}$ & -0.645336 & 1.467327 & -1.17424 & 104 & $\mathrm{C}$ & 12.714465 & -1.796659 & -0.535325 \\
\hline 50 & $\mathrm{H}$ & -1.24307 & 1.052942 & -2.787346 & 105 & $\mathrm{C}$ & 15.132862 & -2.073787 & -0.700218 \\
\hline 51 & $\mathrm{H}$ & -1.618401 & 2.635105 & -2.102517 & 106 & $\mathrm{H}$ & 16.332154 & -0.283081 & -0.681147 \\
\hline 52 & $\mathrm{~N}$ & -2.253234 & -1.786111 & 1.623273 & 107 & $\mathrm{C}$ & 13.838311 & -2.614335 & -0.637176 \\
\hline 53 & $\mathrm{~N}$ & -2.607208 & 0.080202 & -0.300886 & 108 & $\mathrm{H}$ & 11.721508 & -2.230688 & -0.46613 \\
\hline 54 & $\mathrm{C}$ & -8.090039 & 0.689301 & 0.811675 & 109 & $\mathrm{H}$ & 15.988074 & -2.738888 & -0.780072 \\
\hline 55 & $\mathrm{C}$ & -8.064898 & -1.106968 & -0.944301 & 110 & $\mathrm{H}$ & 13.707138 & -3.69287 & -0.661924 \\
\hline
\end{tabular}




\section{NMR Spectra}

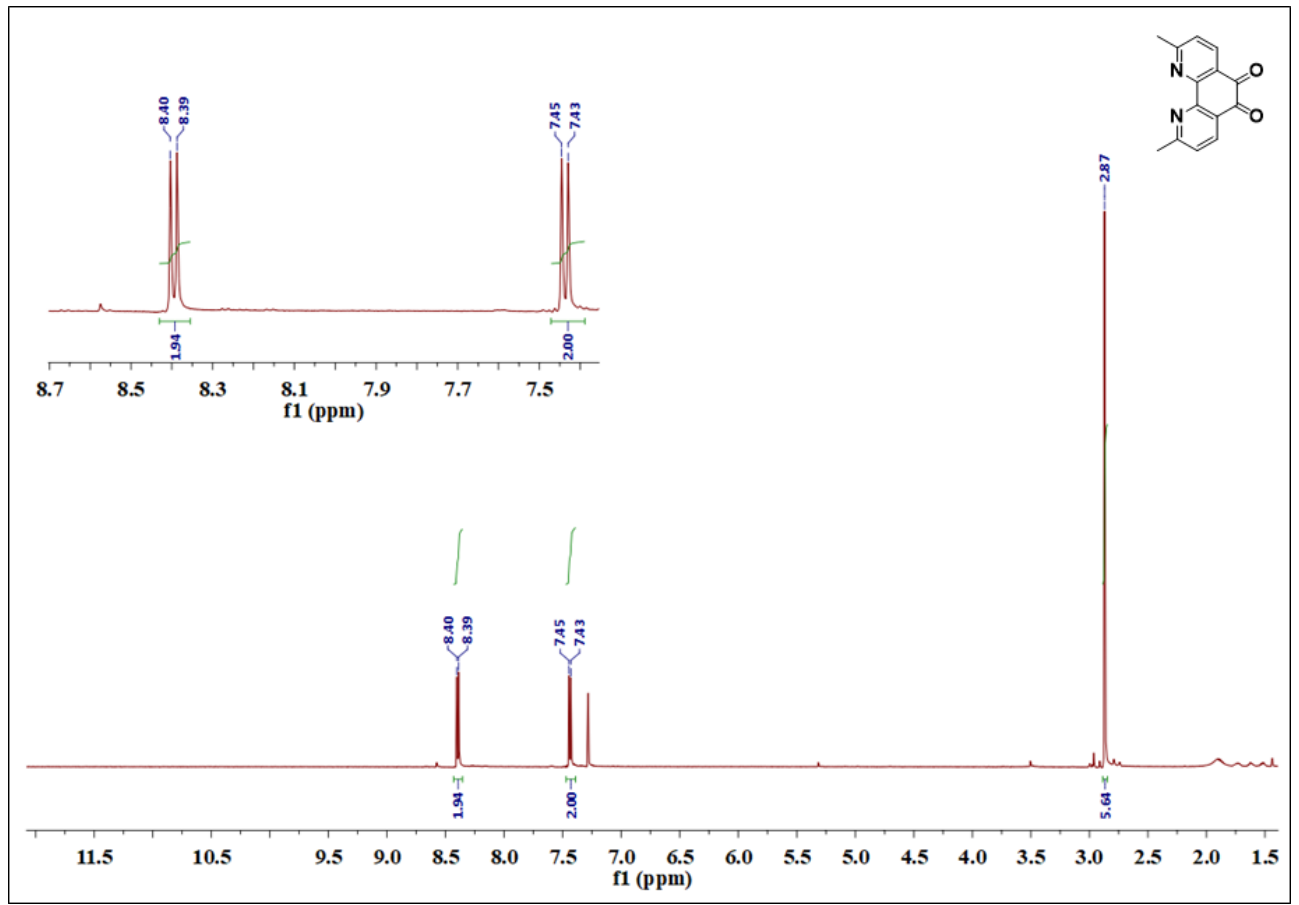

Figure S12: ${ }^{1} \mathrm{H}$ NMR spectrum of 2 in $\mathrm{CDCl}_{3}$

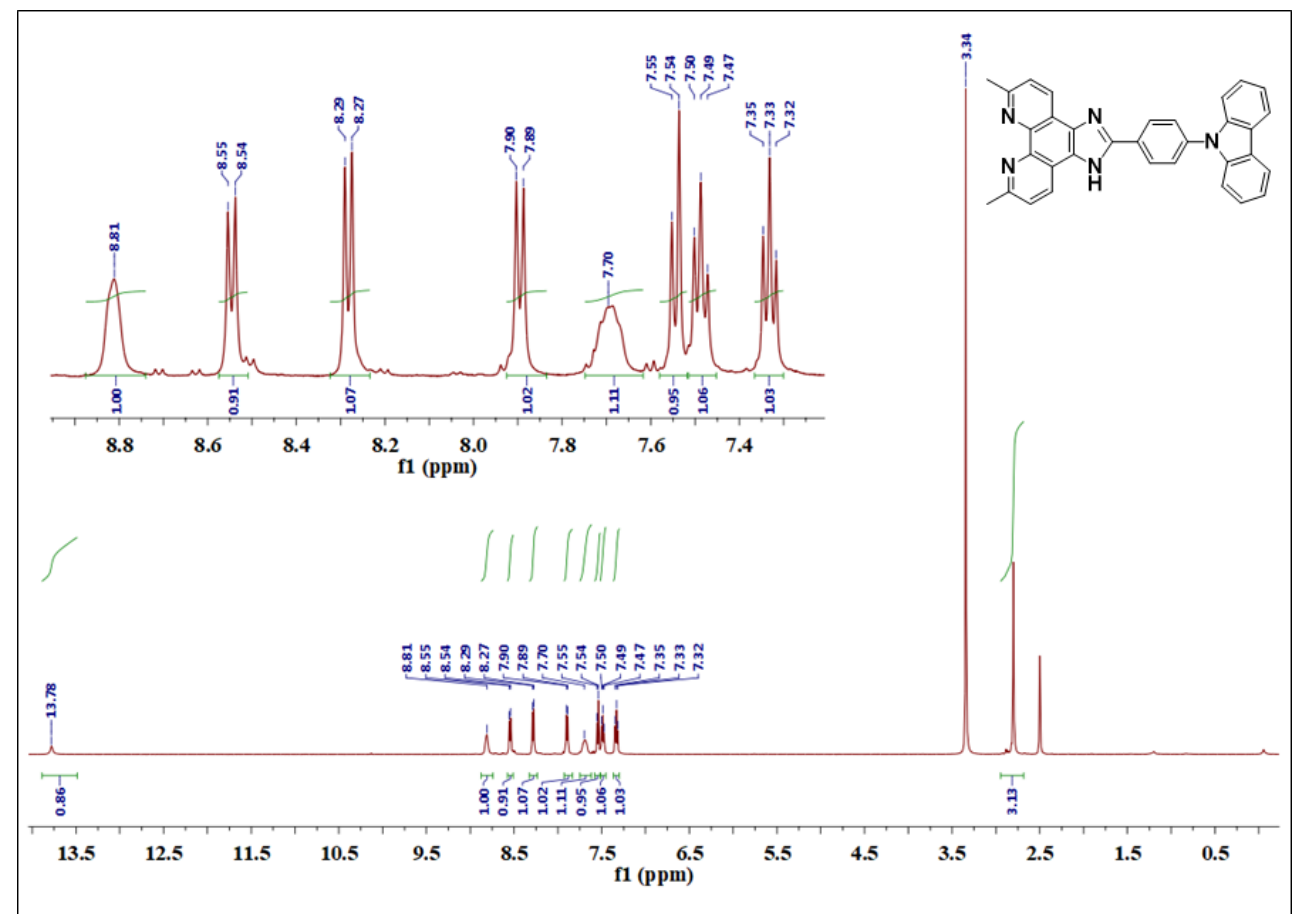

Figure S13. ${ }^{1} \mathrm{H}$ NMR spectrum of D1 in $\left(\mathrm{CD}_{3}\right)_{2} \mathrm{SO}$ 


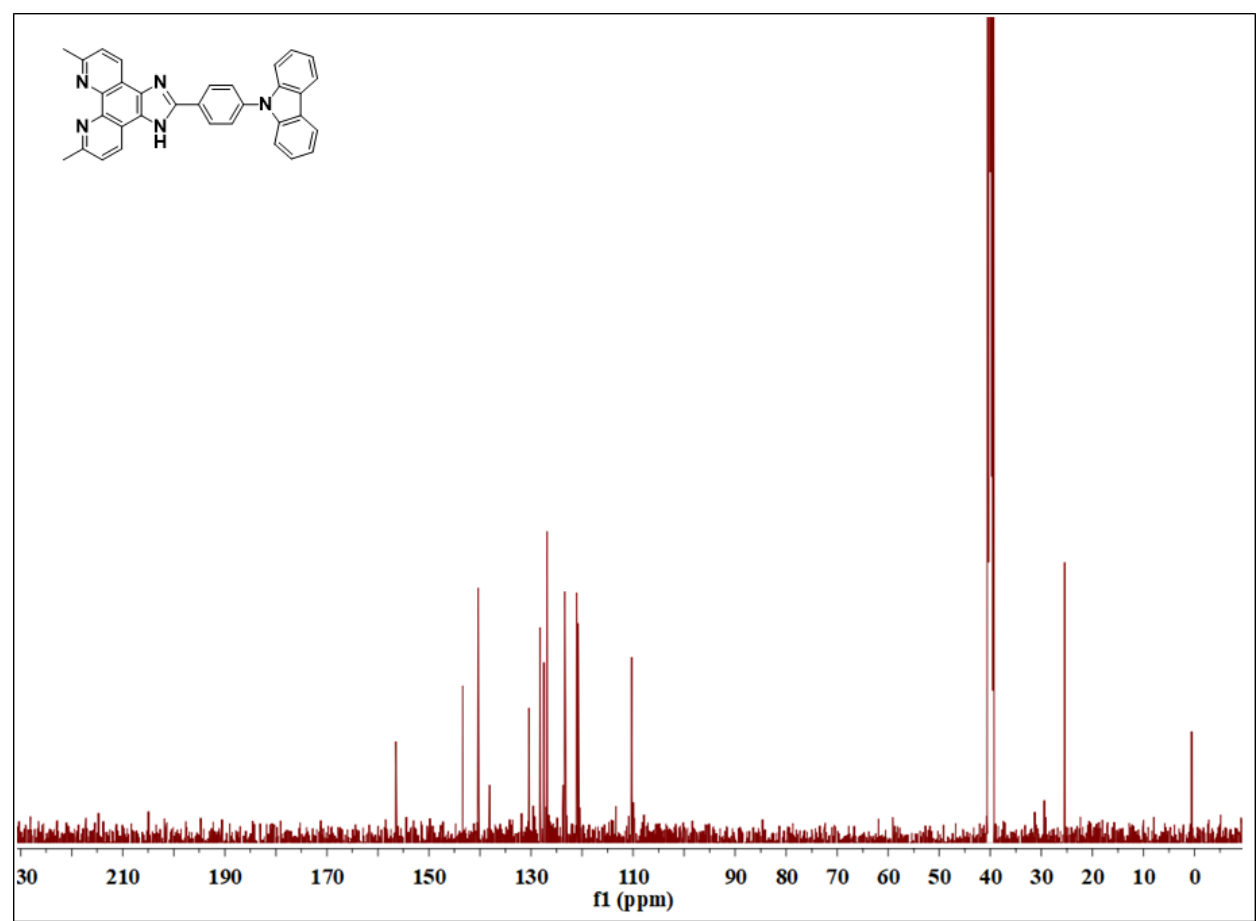

Figure S14. ${ }^{13} \mathrm{C}\left\{{ }^{1} \mathrm{H}\right\}$ NMR spectrum of D1 in $\left(\mathrm{CD}_{3}\right)_{2} \mathrm{SO}$

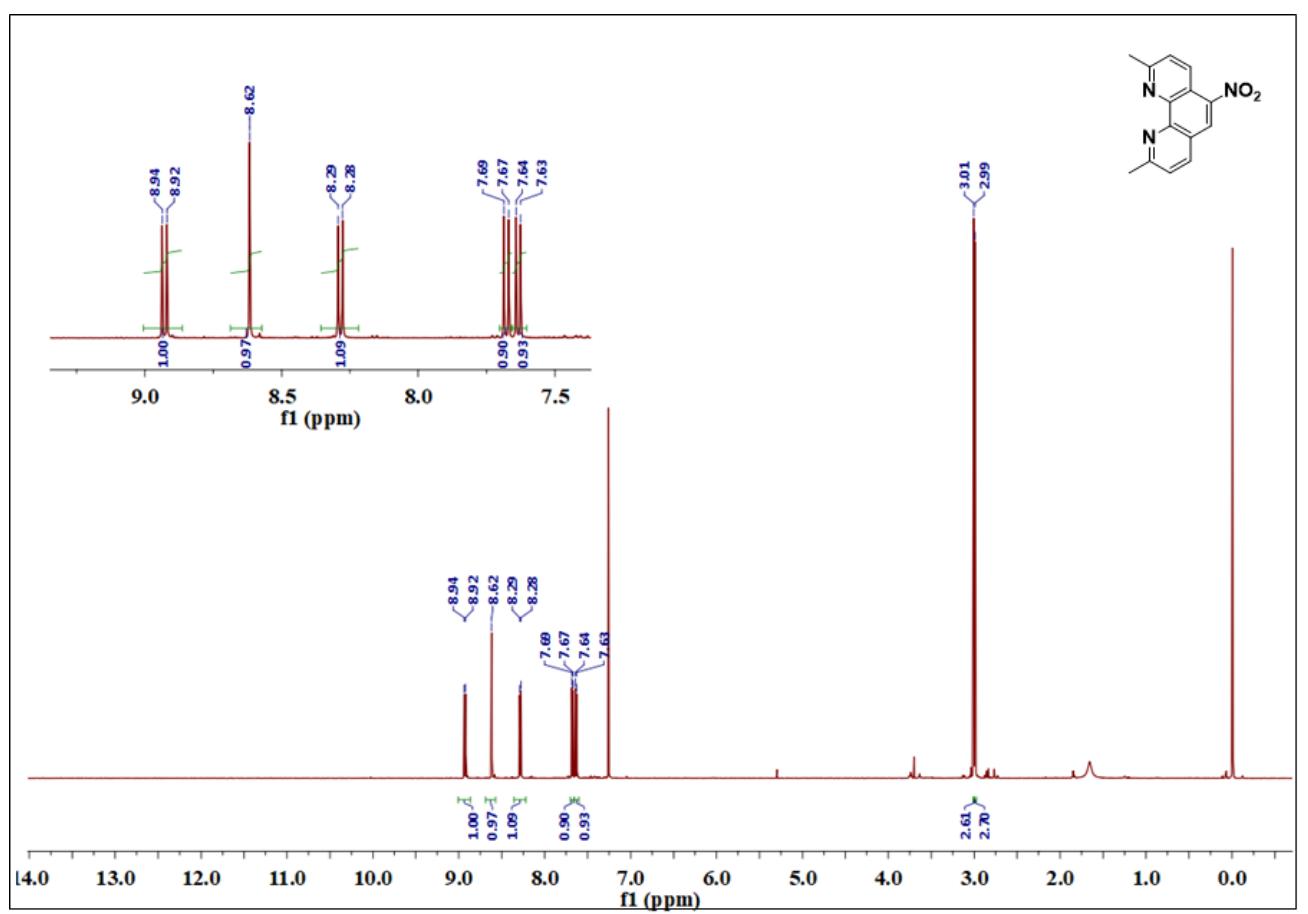

Figure S15. ${ }^{1} \mathrm{H}$ NMR spectrum of 4 in $\mathrm{CDCl}_{3}$ 


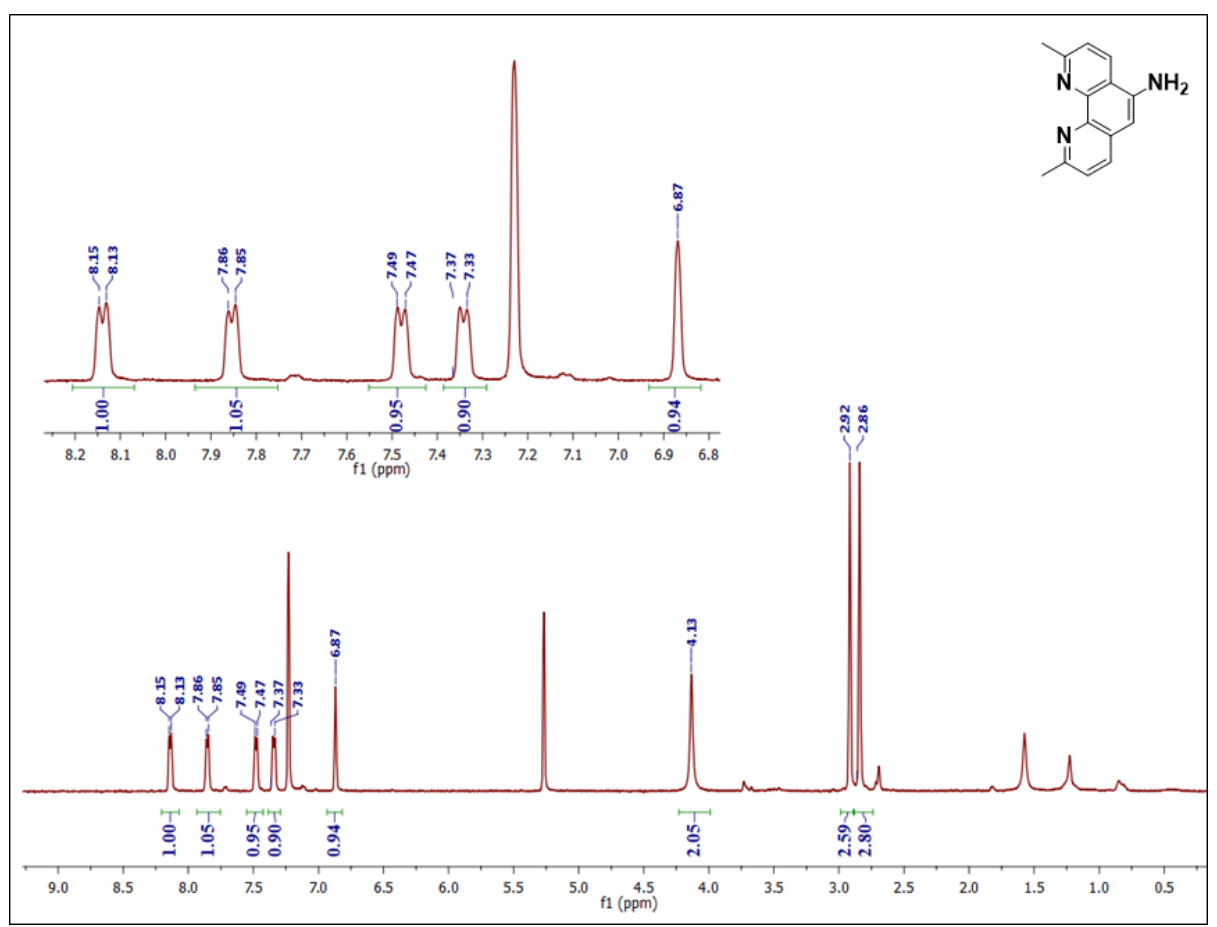

Figure S16. ${ }^{\mathrm{H}} \mathrm{NMR}$ spectrum of 5 in $\mathrm{CDCl}_{3}$

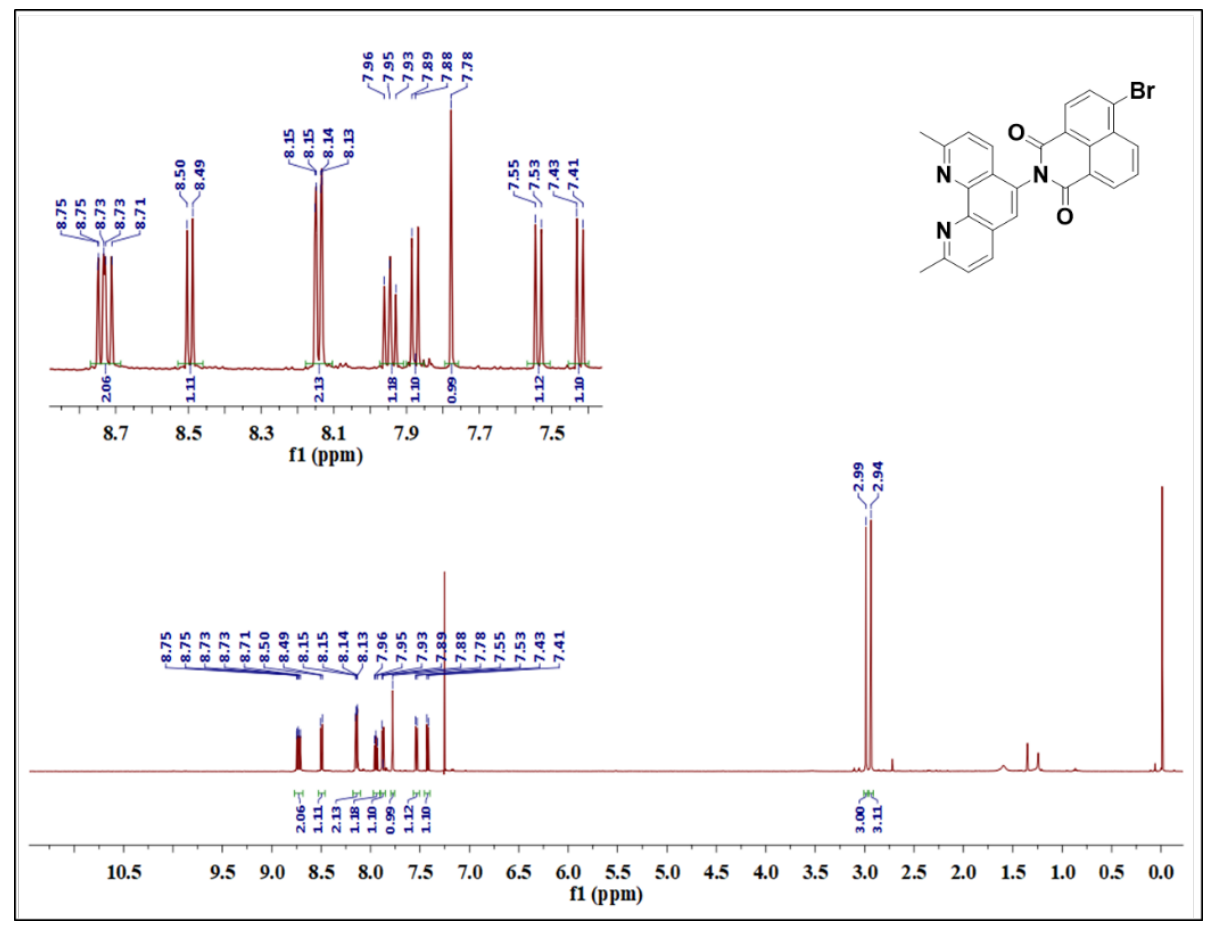

Figure S17. ${ }^{1} \mathrm{H}$ NMR spectrum of $\mathbf{A 1}$ in $\mathrm{CDCl}_{3}$ 


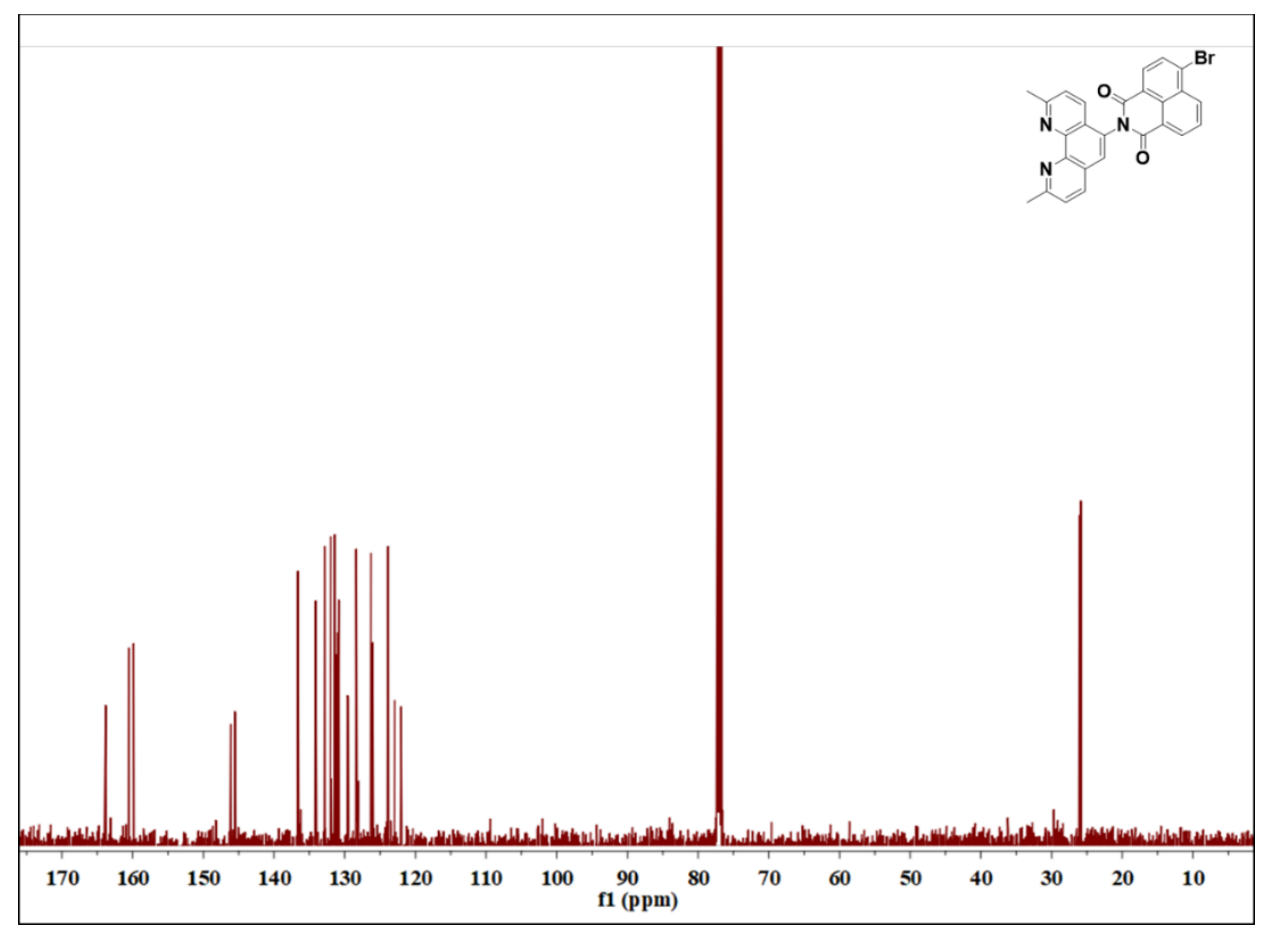

Figure S18. ${ }^{13} \mathrm{C}\left\{{ }^{1} \mathrm{H}\right\}$ NMR spectrum of $\mathbf{A 1}$ in $\mathrm{CDCl}_{3}$

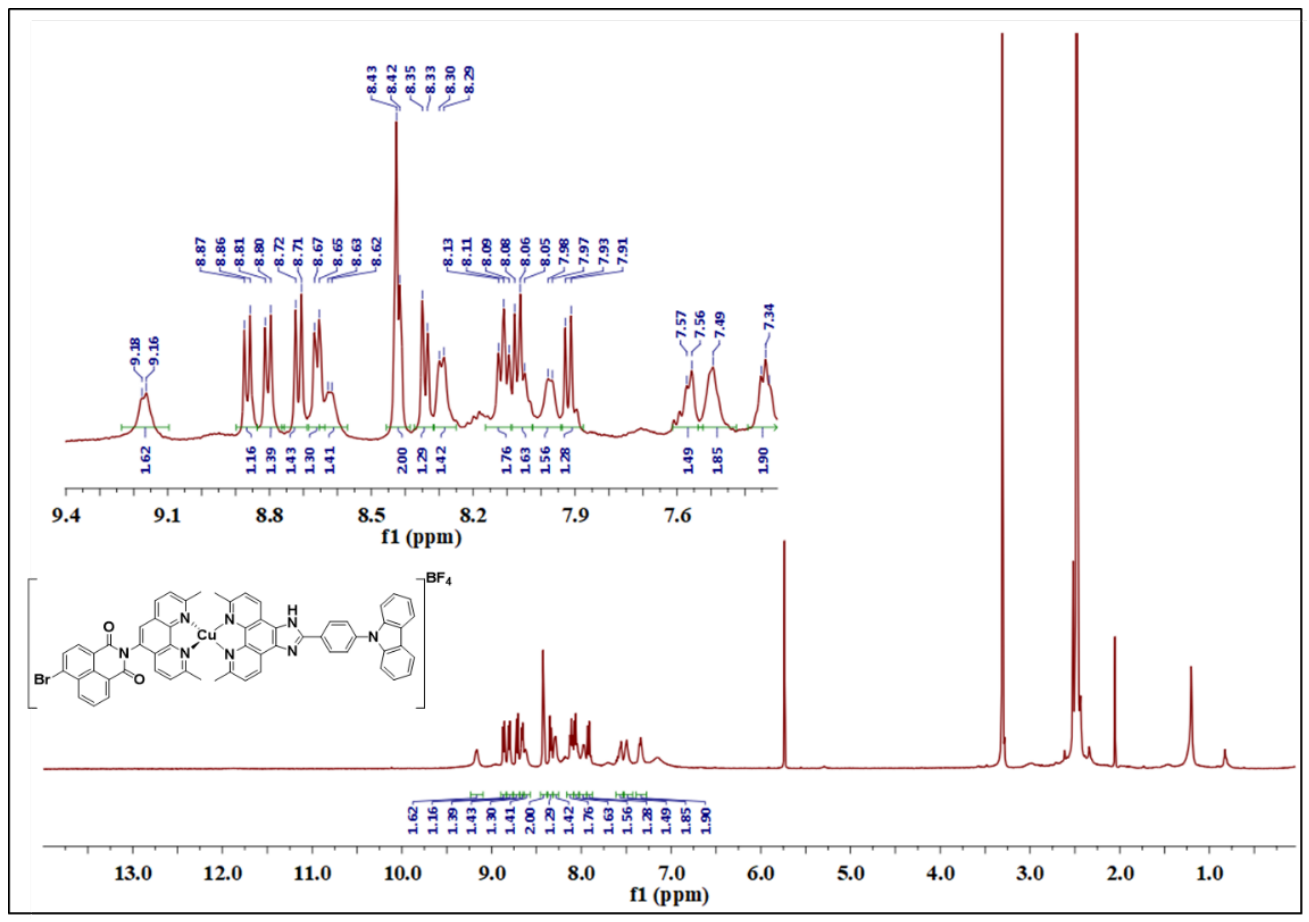

Figure S19. ${ }^{1} \mathrm{H}$ NMR spectrum of D1-C-A1 in $\left(\mathrm{CD}_{3}\right)_{2} \mathrm{SO}$ 


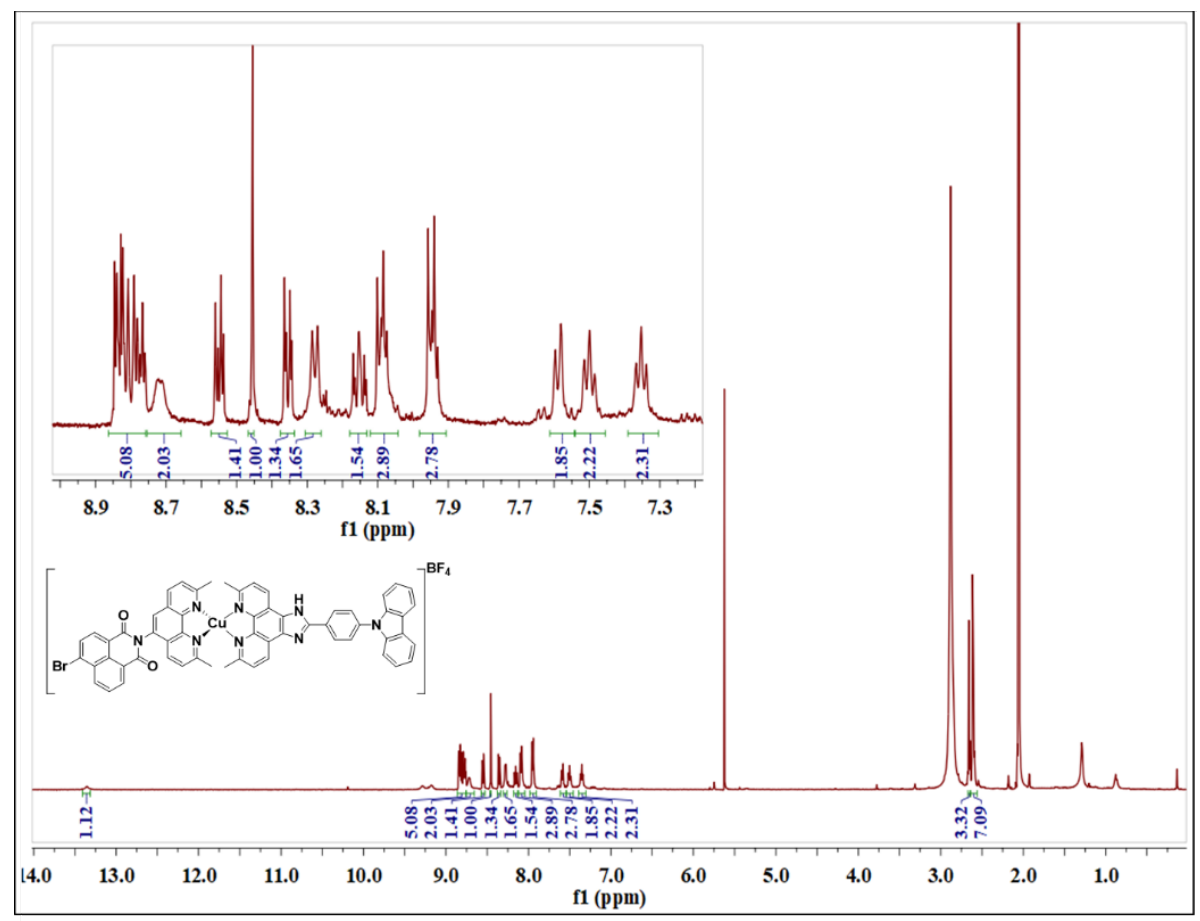

Figure S20. ${ }^{1} \mathrm{H}$ NMR spectrum of D1-C-A1 in $\left(\mathrm{CD}_{3}\right)_{2} \mathrm{CO}$

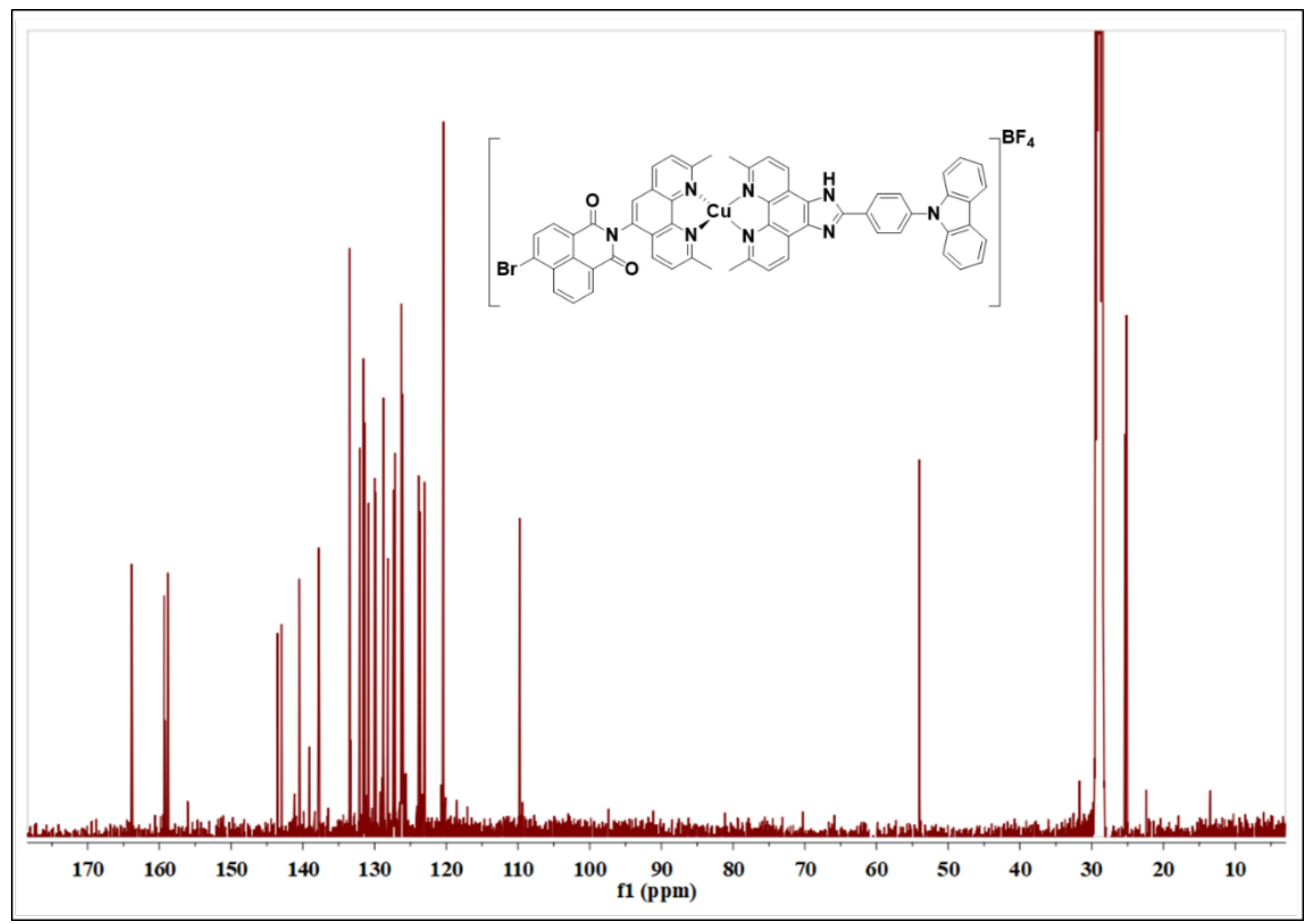

Figure S21. ${ }^{13} \mathrm{C}\left\{{ }^{1} \mathrm{H}\right\}$ NMR spectrum of D1-C-A1 in $\left(\mathrm{CD}_{3}\right)_{2} \mathrm{CO}$ 


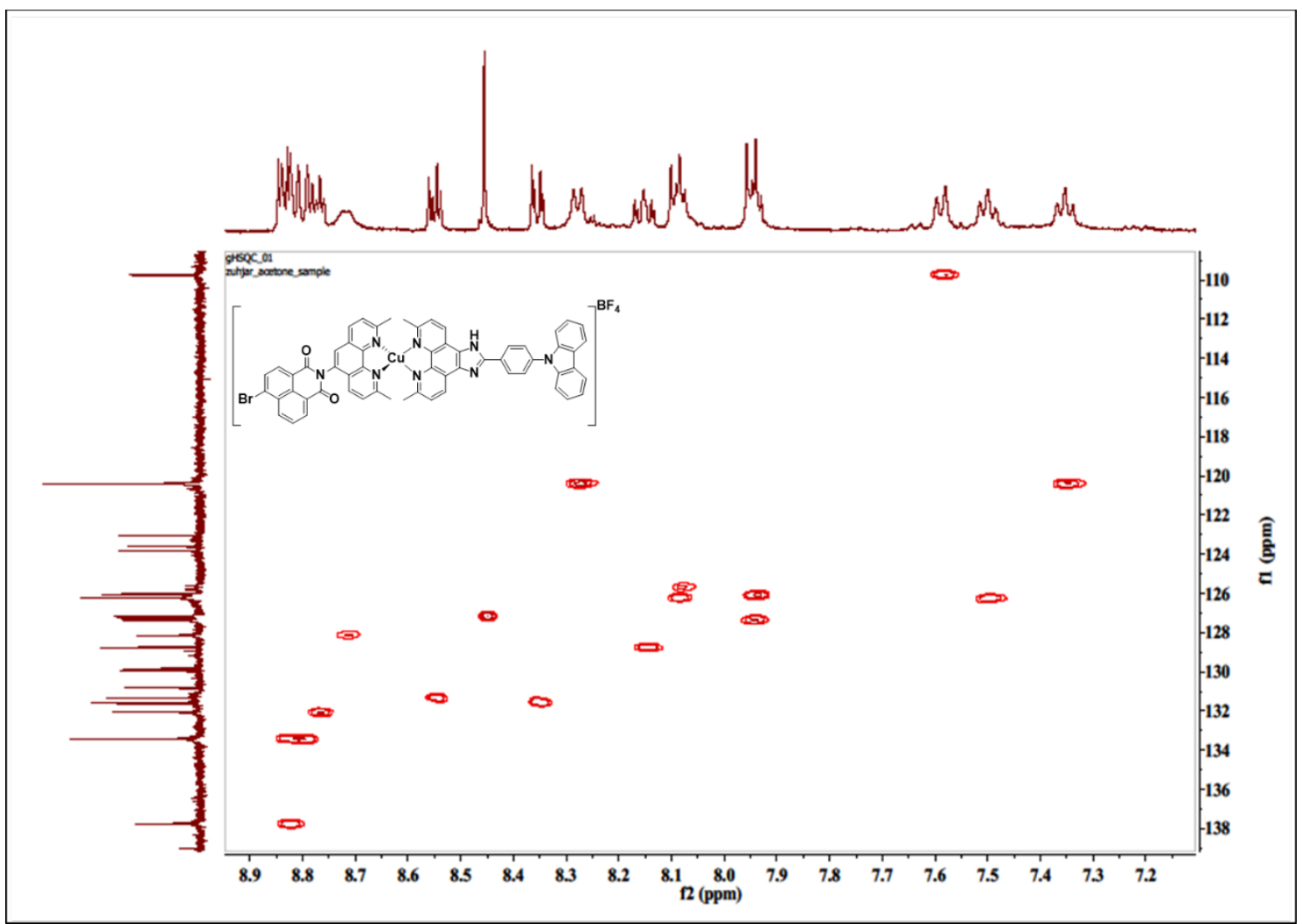

Figure S22. gHSQC spectrum of D1-C-A1 in $\left(\mathrm{CD}_{3}\right)_{2} \mathrm{CO}$ 


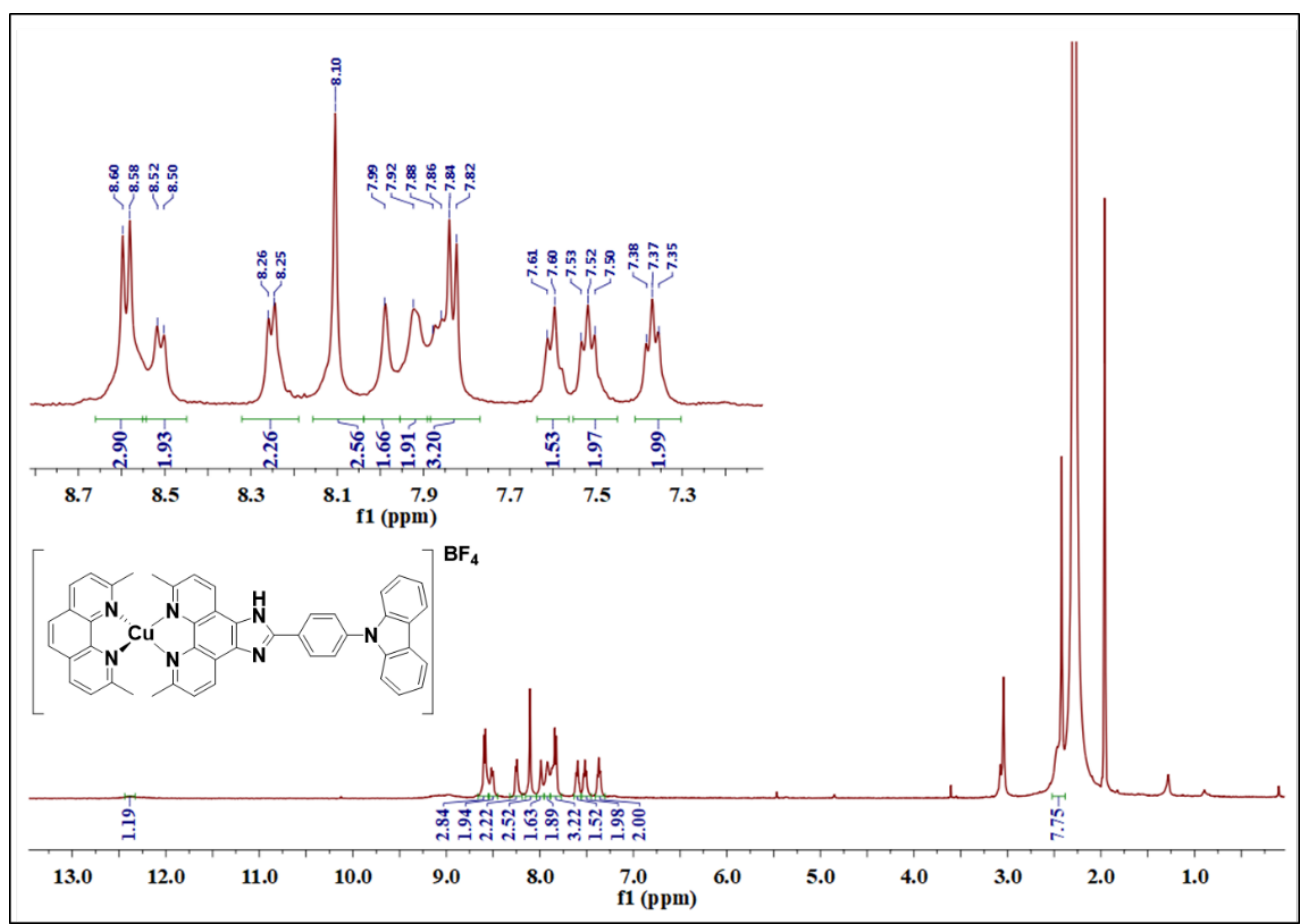

Figure S23. ${ }^{1} \mathrm{H}$ NMR spectrum of D1-C in $\mathrm{CD}_{3} \mathrm{CN}$

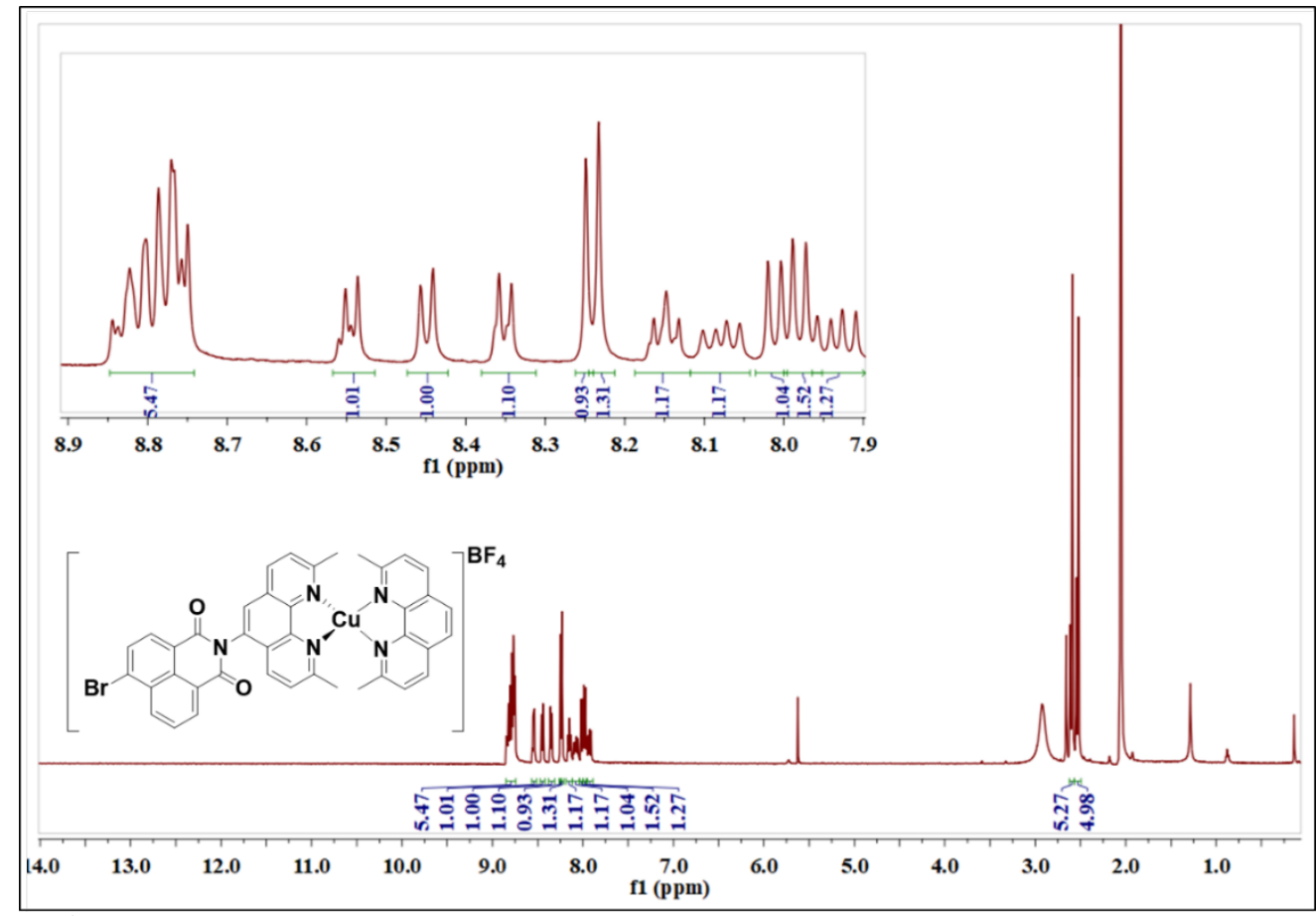

Figure S24. ${ }^{1} \mathrm{H}$ NMR spectrum of C-A1 in $\left(\mathrm{CD}_{3}\right)_{2} \mathrm{CO}$ 


\section{Mass Spectra of D1-C-A1}

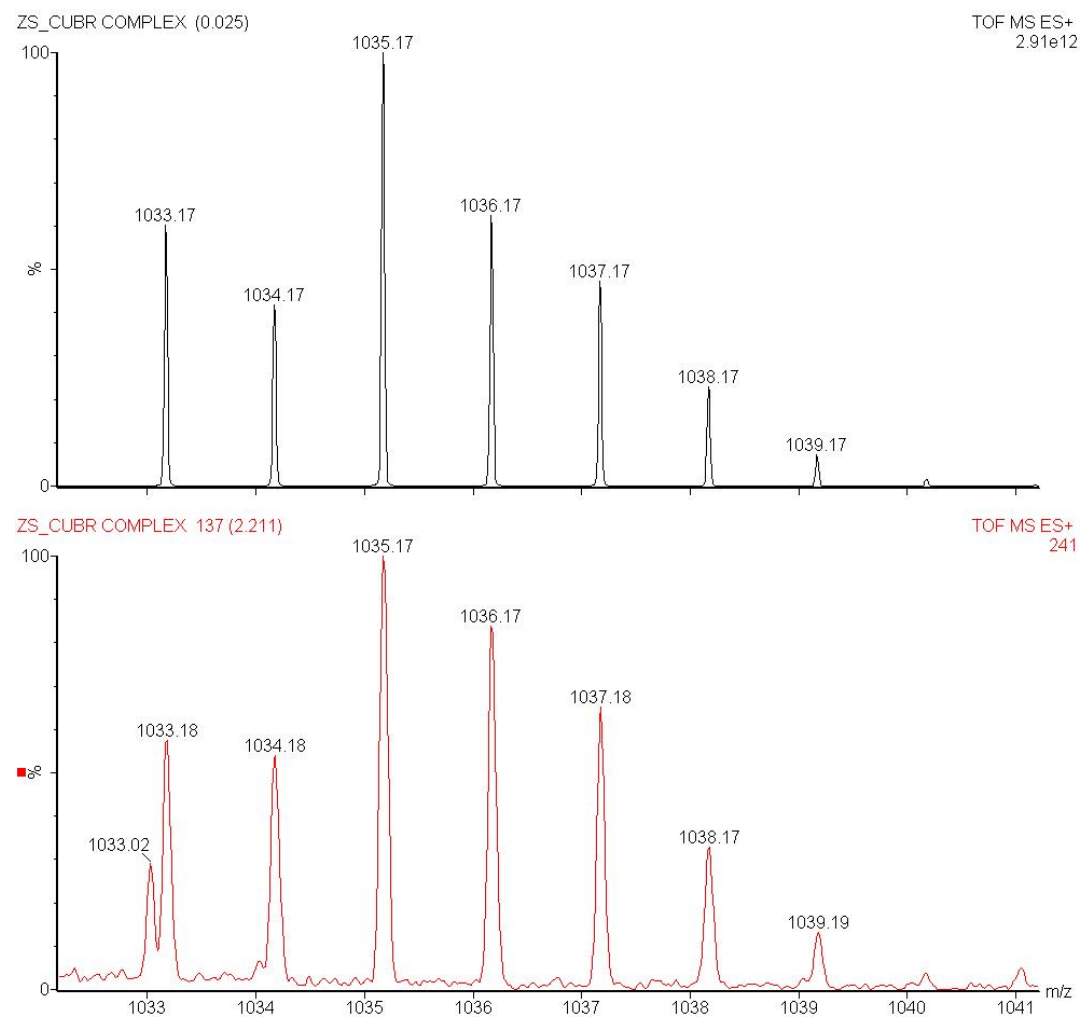

Figure S25. Calculated (top) and collected (bottom) mass spectra for the D1-C-A1 triad. 


\section{Comparison to existing DS-PEC systems}

Table S5. Comparison of the reported work against dye-sensitized photoanodes reported previously. Omitted are tandem systems. No effort is made to distinguish between any results employing methods of chromophore/catalyst protection on the surface.

\begin{tabular}{|c|c|c|c|c|c|c|c|}
\hline Reference & Catalyst $^{a}$ & Absorber $^{a}$ & $\begin{array}{c}\text { Solvent } \\
\text { conditions }\end{array}$ & $\begin{array}{c}\text { Light } \\
\text { intensity } \\
\left(\mathrm{mW} / \mathrm{cm}^{2}\right)\end{array}$ & $\begin{array}{c}\text { Potential } \\
\text { applied V vs. } \\
\text { NHE (vs. } \\
\text { Ag/AgCl) }\end{array}$ & $\begin{array}{c}\text { Approximate } \\
\text { photocurrent } \\
\text { plateau } \\
\left(\mu A / \mathrm{cm}^{2}\right)\end{array}$ & $\begin{array}{l}\text { Maximum } \\
\text { Faradaic } \\
\text { efficiency }\end{array}$ \\
\hline $\begin{array}{l}\text { This } \\
\text { work }\end{array}$ & $\mathrm{Cu}$ & $\mathrm{Cu}$ & $\mathrm{pH} 12$ & $\sim 400$ & $0.2(0)$ & 4 & $76 \%$ \\
\hline 14 & $\mathrm{Ir}$ & Org & $\mathrm{pH} 2.5$ & 200 & $0.51(0.31)$ & $10-20$ & $22 \%$ \\
\hline 15 & $\mathrm{Ru}$ & Org & pH 3.9 & 100 & $0.4(0.2)$ & 25 & $12 \%$ \\
\hline 16 & $\mathrm{Fe}$ & $\mathrm{WO}_{3}$ & $\mathrm{pH} 3$ & 100 & $1.23(1.03)$ & 1100 & $79 \pm 9 \%$ \\
\hline 17 & $\mathrm{Ru}$ & $\mathrm{Ru}$ & pH 6.8 & 300 & $0.2(0)$ & 2000 & $83 \%$ \\
\hline 18 & $\mathrm{Mn}$ & $\mathrm{Ru}$ & pH 6.5 & 100 & $1.2(1.0)$ & 31 & $90 \%$ \\
\hline 19 & Ir & $\mathrm{Zn}$ & - & 200 & $0.3(0.1)$ & 30 & - \\
\hline 20 & $\mathrm{Ru}$ & $\mathrm{Ru}$ & $\mathrm{pH} 4.65$ & 100 & $0.6(0.4)$ & 310 & $86 \pm 12 \%$ \\
\hline 21 & $\mathrm{Ru}$ & $\mathrm{Ru}$ & pH 4.65 & 100 & $0.5(0.3)$ & 250 & $67 \%$ \\
\hline 22 & $\mathrm{Ru}$ & $\mathrm{Ru}$ & pH 4.6 & 100 & $0.45(0.25)$ & 350 & $75.5 \%$ \\
\hline 23 & $\mathrm{Ru}$ & $\mathrm{Ru}$ & pH 7.5 & 100 & $0.4(0.2)$ & 1000 & $73 \%$ \\
\hline 24 & $\mathrm{Ru}$ & $\mathrm{Ru} / \mathrm{Org}$ & $\mathrm{pH} 4.65$ & 100 & $0.6(0.4)$ & 1000 & $49-100 \%$ \\
\hline 25 & $\mathrm{Ru}$ & $\mathrm{Ru}$ & pH 4.65 & 100 & $0.4(0.2)$ & 207 & $41-70 \%$ \\
\hline 26 & $\mathrm{Ru}$ & Org & $\mathrm{pH} 4.8$ & 100 & $0.4(0.2)$ & 400 & $24-79 \%$ \\
\hline 27 & $\mathrm{Ru}$ & Org & pH 7 & $\begin{array}{c}7.8-90 \\
\mathrm{~mW}\end{array}$ & $0.5(0.3)$ & 82 & $10.5 \%$ \\
\hline 28 & $\mathrm{Ru}$ & $\mathrm{Ru}$ & pH 5.7 & 100 & $0.3(0.1)$ & 800 & $74 \%$ \\
\hline
\end{tabular}

${ }^{a}$ Catalyst and light absorber/chromophore are denoted by the metal center (entirely organic moieties are denoted as "Org"). 


\section{References}

(1) Dragonetti, C.; Magni, M.; Colombo, A.; Fagnani, F.; Roberto, D.; Melchiorre, F.; Biagini, P.; Fantacci, S. Towards efficient sustainable full-copper dye-sensitized solar cells. Dalton Trans. 2019, 48 (26), 9703.

(2) Franco, F.; Cometto, C.; Garino, C.; Minero, C.; Sordello, F.; Nervi, C.; Gobetto, R. Photo- and Electrocatalytic Reduction of $\mathrm{CO} 2$ by $\left[\operatorname{Re}(\mathrm{CO}) 3\left\{\alpha, \alpha^{\prime}\right.\right.$-Diimine-(4-piperidinyl1,8-naphthalimide)\}Cl] Complexes. Eur. J. Inorg. Chem. 2014, 2015, 296.

(3) Sherman, B. D.; Sheridan, M. V.; Dares, C. J.; Meyer, T. J. Two Electrode CollectorGenerator Method for the Detection of Electrochemically or Photoelectrochemically Produced O2. Anal. Chem. 2016, 88 (14), 7076.

(4) Schmittel, M.; Ganz, A. Stable mixed phenanthroline copper(i) complexes. Key building blocks for supramolecular coordination chemistry. Chem. Commun. 1997, (11), 999.

(5) Kasamechonchung, P.; Horprathum, M.; Boonpavanitchakul, K.; Supaka, N.; Prompinit, P.; Kangwansupamonkon, W.; Somboonkaew, A.; Wetcharungsri, J.; Pratontep, S.;

Porntheeraphat, S.et al. Morphology-controlled seed-assisted hydrothermal ZnO nanowires via critical concentration for nucleation and their photoluminescence properties. Phys. Status Solidi A 2015, 212 (2), 394.

(6) Yarur Villanueva, F.; Manioudakis, J.; Naccache, R.; Majewski, M. B. Carbon DotSensitized Photoanodes for Visible Light-Driven Organic Transformations. ACS Appl. Nano Mater. 2020, 3 (3), 2756.

(7) Tamirat, A. G.; Rick, J.; Dubale, A. A.; Su, W.-N.; Hwang, B.-J. Using hematite for photoelectrochemical water splitting: a review of current progress and challenges. Nanoscale Horiz. 2016, 1 (4), 243.

(8) Frisch, M. J.; Trucks, G. W.; Schlegel, H. B.; Scuseria, G. E.; Robb, M. A.; Cheeseman, J. R.; Scalmani, G.; Barone, V.; Petersson, G. A.; Nakatsuji, H.et al. Wallingford, CT, 2016.

(9) Zhao, Y.; Pu, J.; Lynch, B. J.; Truhlar, D. G. Tests of second-generation and thirdgeneration density functionals for thermochemical kinetics. PCCP 2004, 6 (4), 673.

(10) Sosa, C.; Andzelm, J.; Elkin, B. C.; Wimmer, E.; Dobbs, K. D.; Dixon, D. A. A local density functional study of the structure and vibrational frequencies of molecular transition-metal compounds. J. Phys. Chem. 1992, 96 (16), 6630.

(11) Godbout, N.; Salahub, D. R.; Andzelm, J.; Wimmer, E. Optimization of Gaussian-type basis sets for local spin density functional calculations. Part I. Boron through neon, optimization technique and validation. Can. J. Chem. 1992, 70 (2), 560.

(12) Dennington, R.; Keith, T. A.; Millam, J. M.; 5 ed.; Semichem Inc.: Shawnee Mission, KS, 2016.

(13) O'boyle, N. M.; Tenderholt, A. L.; Langner, K. M. cclib: A library for packageindependent computational chemistry algorithms. J. Comput. Chem. 2008, 29 (5), 839.

(14) Kamire, R. J.; Materna, K. L.; Hoffeditz, W. L.; Phelan, B. T.; Thomsen, J. M.; Farha, O. K.; Hupp, J. T.; Brudvig, G. W.; Wasielewski, M. R. Photodriven Oxidation of SurfaceBound Iridium-Based Molecular Water-Oxidation Catalysts on Perylene-3,4dicarboximide-Sensitized $\mathrm{TiO} 2$ Electrodes Protected by an A12O3 Layer. J. Phys. Chem. C 2017, 121 (7), 3752.

(15) Eom, Y. K.; Nhon, L.; Leem, G.; Sherman, B. D.; Wang, D.; Troian-Gautier, L.; Kim, S.; Kim, J.; Meyer, T. J.; Reynolds, J. R.et al. Visible-Light-Driven Photocatalytic Water 
Oxidation by a $\pi$-Conjugated Donor-Acceptor-Donor Chromophore/Catalyst Assembly. ACS Energy Lett. 2018, 3 (9), 2114.

(16) Klepser, B. M.; Bartlett, B. M. Anchoring a Molecular Iron Catalyst to Solar-Responsive WO3 Improves the Rate and Selectivity of Photoelectrochemical Water Oxidation. J. Am. Chem. Soc. 2014, 136 (5), 1694.

(17) Gao, Y.; Ding, X.; Liu, J.; Wang, L.; Lu, Z.; Li, L.; Sun, L. Visible Light Driven Water Splitting in a Molecular Device with Unprecedentedly High Photocurrent Density. J. Am. Chem. Soc. 2013, 135 (11), 4219.

(18) Brimblecombe, R.; Koo, A.; Dismukes, G. C.; Swiegers, G. F.; Spiccia, L. Solar Driven Water Oxidation by a Bioinspired Manganese Molecular Catalyst. J. Am. Chem. Soc. 2010, 132 (9), 2892.

(19) Moore, G. F.; Blakemore, J. D.; Milot, R. L.; Hull, J. F.; Song, H.-e.; Cai, L.; Schmuttenmaer, C. A.; Crabtree, R. H.; Brudvig, G. W. A visible light water-splitting cell with a photoanode formed by codeposition of a high-potential porphyrin and an iridium water-oxidation catalyst. Energy Environ. Sci. 2011, 4 (7), 2389.

(20) Wang, D.; Wang, L.; Brady, M. D.; Dares, C. J.; Meyer, G. J.; Meyer, T. J.; Concepcion, J. J. Self-Assembled Chromophore-Catalyst Bilayer for Water Oxidation in a DyeSensitized Photoelectrosynthesis Cell. J. Phys. Chem. C 2019, 123 (50), 30039.

(21) Wang, D.; Sampaio, R. N.; Troian-Gautier, L.; Marquard, S. L.; Farnum, B. H.; Sherman, B. D.; Sheridan, M. V.; Dares, C. J.; Meyer, G. J.; Meyer, T. J. Molecular Photoelectrode for Water Oxidation Inspired by Photosystem II. J. Am. Chem. Soc. 2019, 141 (19), 7926. (22) Liu, Q.; Wang, D.; Shan, B.; Sherman, B. D.; Marquard, S. L.; Eberhart, M. S.; Liu, M.; Li, C.; Meyer, T. J. Light-driven water oxidation by a dye-sensitized photoanode with a chromophore/catalyst assembly on a mesoporous double-shell electrode. J. Chem. Phys. 2019, 150 (4), 041727.

(23) Wu, L.; Eberhart, M.; Nayak, A.; Brennaman, M. K.; Shan, B.; Meyer, T. J. A Molecular Silane-Derivatized Ru(II) Catalyst for Photoelectrochemical Water Oxidation. J. Am. Chem. Soc. 2018, 140 (44), 15062.

(24) Wang, D.; Eberhart, M. S.; Sheridan, M. V.; Hu, K.; Sherman, B. D.; Nayak, A.; Wang, Y.; Marquard, S. L.; Dares, C. J.; Meyer, T. J. Stabilized photoanodes for water oxidation by integration of organic dyes, water oxidation catalysts, and electron-transfer mediators. Proc. Natl. Acad. Sci. U.S.A. 2018, 115 (34), 8523.

(25) Wang, D.; Marquard, S. L.; Troian-Gautier, L.; Sheridan, M. V.; Sherman, B. D.; Wang, Y.; Eberhart, M. S.; Farnum, B. H.; Dares, C. J.; Meyer, T. J. Interfacial Deposition of $\mathrm{Ru}(\mathrm{II})$ Bipyridine-Dicarboxylate Complexes by Ligand Substitution for Applications in Water Oxidation Catalysis. J. Am. Chem. Soc. 2018, 140 (2), 719.

(26) Eberhart, M. S.; Wang, D.; Sampaio, R. N.; Marquard, S. L.; Shan, B.; Brennaman, M. K.; Meyer, G. J.; Dares, C.; Meyer, T. J. Water Photo-oxidation Initiated by SurfaceBound Organic Chromophores. J. Am. Chem. Soc. 2017, 139 (45), 16248.

(27) Alibabaei, L.; Dillon, R. J.; Reilly, C. E.; Brennaman, M. K.; Wee, K.-R.; Marquard, S. L.; Papanikolas, J. M.; Meyer, T. J. Chromophore-Catalyst Assembly for Water Oxidation Prepared by Atomic Layer Deposition. ACS Appl. Mater. Interfaces 2017, 9 (44), 39018.

(28) Sherman, B. D.; Xie, Y.; Sheridan, M. V.; Wang, D.; Shaffer, D. W.; Meyer, T. J.; Concepcion, J. J. Light-Driven Water Splitting by a Covalently Linked Ruthenium-Based Chromophore-Catalyst Assembly. ACS Energy Lett. 2017, 2 (1), 124. 